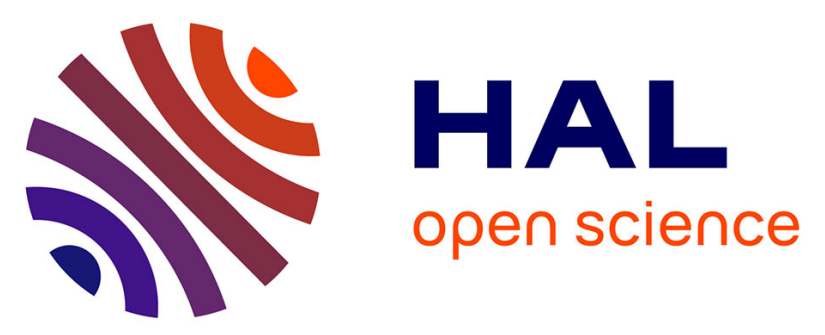

\title{
Calcium mediated DNA binding in non-lamellar structures formed by DOPG/glycerol monooleate
}

Nina Královič - Kanjaková, Lukáš Hubč́k, Alexander Búcsi, Mária Klacsová, Sophie Combet, José Teixeira, Juan Carlos Martínez, Daniela Uhríková

\section{- To cite this version:}

Nina Královič - Kanjaková, Lukáš Hubčík, Alexander Búcsi, Mária Klacsová, Sophie Combet, et al.. Calcium mediated DNA binding in non-lamellar structures formed by DOPG/glycerol monooleate. Chemistry and Physics of Lipids, 2021, 239, pp.105118. 10.1016/j.chemphyslip.2021.105118 . hal03335094

\author{
HAL Id: hal-03335094 \\ https://hal.science/hal-03335094
}

Submitted on 25 Nov 2021

HAL is a multi-disciplinary open access archive for the deposit and dissemination of scientific research documents, whether they are published or not. The documents may come from teaching and research institutions in France or abroad, or from public or private research centers.
L'archive ouverte pluridisciplinaire $\mathbf{H A L}$, est destinée au dépôt et à la diffusion de documents scientifiques de niveau recherche, publiés ou non, émanant des établissements d'enseignement et de recherche français ou étrangers, des laboratoires publics ou privés. 


\title{
Calcium mediated DNA binding in non-lamellar structures formed by DOPG/glycerol monooleate
}

\author{
Nina Královič - Kanjaková ${ }^{1}$, Lukáš Hubčík ${ }^{1}$, Alexander Búcsi' ${ }^{1}$, Mária Klacsová1, Sophie \\ Combet $^{2}$, José Teixeira ${ }^{2}$, Juan Carlos Martínez ${ }^{3}$, Daniela Uhríková*1 \\ ${ }^{1}$ Department of Physical Chemistry of Drugs, Faculty of Pharmacy, Comenius \\ University in Bratislava, Odbojárov 10, 83232 Bratislava, Slovakia \\ ${ }^{2}$ Université Paris-Saclay, Laboratoire Léon Brillouin, UMR12 CEA-CNRS, CEA \\ Saclay, F 91191 Gif-sur-Yvette Cedex, France \\ ${ }^{3}$ ALBA Synchrotron, Cerdanyola del Vallés, 08290 Barcelona, Spain
}

*Corresponding author, e-mail: uhrikova@,fpharm.uniba.sk

ORCID: Daniela Uhríková 0000-0002-4397-1283 


\begin{abstract}
In order to test an encapsulation method of short fragmented DNA ( $20-300 \mathrm{bp})$, we study the solubilisation in $150 \mathrm{mM}$ solution of $\mathrm{NaCl}$ of a cubic phase formed by glycerol monooleate (GMO) with negatively charged dioleoylphosphatidylglycerol (DOPG) up to the level of unilamellar vesicles and, subsequently, the restoration of the cubic phase using $\mathrm{Ca}^{2+}$ cations. We performed small angle X-ray and neutron scattering (SAXS and SANS) to follow structural changes in DOPG/GMO mixtures induced by increasing DOPG content. The cubic phase (Pn3m space group) is preserved up to $\sim 11 \mathrm{~mol} \%$ of DOPG in DOPG/GMO. Above $20 \mathrm{~mol} \%$, the SANS curves are typical of unilamellar vesicles. The thickness of the DOPG/GMO lipid bilayer $\left(d_{L}\right)$ decreases slightly with increasing fraction of DOPG. The addition of $15 \mathrm{mM}$ of $\mathrm{CaCl}_{2}$ solution shields the electrostatic repulsions of DOPG molecules, increases slightly $d_{L}$ and restores the cubic structures in the mixtures up to $\sim 37 \mathrm{~mol} \%$ of DOPG. Zeta potential shows negative surface charge. The analysis of the data provides the radius of the water nano-channels of the formed non-lamellar structures. We discuss their dimensions with respect to DNA binding. In addition, $\mathrm{Ca}^{2+}$ mediates DNA - DOPG/GMO binding. The formed hexagonal phase, $H_{I I}$, binds less of DNA in comparison with cubic phases $(\sim 6 \mathrm{wt} \%$ and $\sim 20 \mathrm{wt} \%$ of the total amount, respectively). The studied system can be utilized as anionic $Q_{I I}$ delivery vector for genetic material.
\end{abstract}

Keywords: DNA, DOPG, glycerol monooleate, calcium, SAXS, SANS

\title{
Introduction
}

Lyotropic liquid-crystalline phases formed by the swelling of certain lipids (lipid/surfactant mixtures) when exposed to aqueous environments comprise: onedimensional lamellar phase $(L)$ known as liposomes in excess water; structurally more complex two dimensional columnar hexagonal phases $(H)$; and three dimensional cubic phases $(Q)$ of symmetries characterized by space groups. Luzzati (1997) pointed out the relevancy and function of cubic phases in biological systems, while Engström and coworkers (1999) proposed cubic phases as carriers for the drug delivery. Bicontinuous inverted cubic phases $\left(Q_{I I}\right)$ consisting of a pair of interpenetrating but noncontacting aqueous channels separated by a single, continuous lipid bilayer attract a particular attention due to their capability to accommodate a drug into both the water phase, and into the hydrophobic matrix (Angelov et al. 2014; Shah et al. 2001; Chen et al. 2014). There are three types of lipid bicontinuous cubic phases: the primitive $(\operatorname{Im} 3 \mathrm{~m})$, the double diamond $(P n 3 m)$ and the gyroid (Ia3d) (Seddon et al. 1993). It is worth mentioning that micellar cubic phases are studied as drug carriers too (Yaghmur and Rappolt 2013; Galliková et al. 2018; Fong et al. 2020). Potential drug carrier properties of $Q_{I I}$ and inverted hexagonal $\left(H_{I I}\right)$ phases have been investigated following subcutaneous, transdermal, oral, ophthalmic, muconasal and other administrations. An 
extensive tabulation of loaded drug molecules, lipid compositions and conditions were reviewed recently (Zhai et al. 2019; Barriga at al. 2019). It is established that cubic phases can accommodate proteins significantly larger than the aqueous channel within which the macromolecule was contained (Angelova et al. 2003; Clogston and Caffrey 2005; Angelov et al. 2017).

In the field of gene therapy, the effective treatment depends on the successful transportation of large polyanionic DNA molecules through the cell membrane. Lipidbased gene delivery vectors facilitate increased uptake of nucleic acids and look promising for gene therapies (Lasic 1997; Chen et al. 2016). However, from the therapeutic point of view, the level of transfection mediated by lipid-based DNA delivery vectors, lipoplexes, has low efficiency. It is well accepted that progress in transfection efficiency requires a full understanding of the roles played by both the physicochemical properties of gene delivery carriers, and cellular processes. The latter represents many complex steps starting with the association of the lipoplex with a cell and ending with successful DNA transcription in the nucleus. The relation between the stereochemistry of used amphiphiles and the resulting morphology of the carrier (Safinya et al. 2014; Hubčík et al. 2015; Uhríková and Pullmannová 2014; Pullmannová et al. 2012) is important for a targeted design of lipoplexes. The formation of lipoplexes is a result of the electrostatic interaction between DNA polyanion and cationic liposomes. The reaction is endothermic and rapid (Barreleiro et al. 2000), resulting in the formation of string-like colloids with an ordered internal structure (Gershon et al. 1993; Koltover et al. 1999). The following microstructures have been identified: (i) the condensed lamellar phase $L^{C}$ (Lasic et al. 1997; Rädler et al. 1997); (ii) hexagonal phases $H_{I I}{ }^{C}$ and $H_{I}$ (Koltover et al. 1998; Ewert et al. 2006 ); (iii) cubic phases (Leal et al. 2010), which were tested as gene delivery carriers.

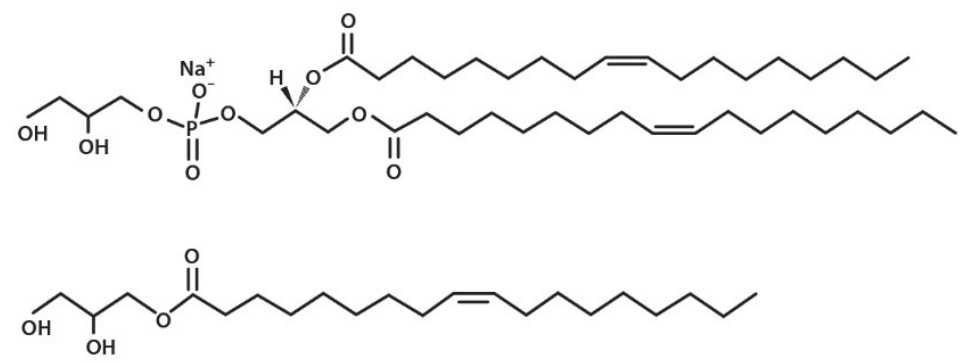

Fig. 1. Structural formulae of dioleoyl phosphatidylglycerol, sodium salt (DOPG) and glycerol monooleate (GMO).

Glycerol monooleate (GMO) (Fig. 1) is the constituent of lipidic cubic phases, with space groups Pn3m, and Ia3d (Briggs et al. 1996; Qiu and Caffrey 2000). GMO is non-toxic, biocompatible, biodegradable and used in pharmaceutical formulations. Adjusting the size of the $Q_{I I}$ aqueous nanochannels makes it possible to control their capacity for encapsulating different molecules. Mixtures of GMO and amphiphilic molecules are a way of such tuning (Cherezov et al. 2002; Angelov et al. 2003; Awad et al. 2005; Tyler et al. 2015). Preparation methods of cubic structures for genetic material delivery are under discussion (Zhai et al. 2019; 
Chen et al. 2016). In the case of DNA, the rigidity and large size of its strands are the limiting factors in its accommodation to the nanochannels of the lipidic cubic structure (Sarkar et al. 2020).

Short fragmented double or single stranded nucleic acids, such as siRNA miRNA, can easily fit into water nanochannels of the $Q_{I I}$ phase: A systematic study of DNA fragments with increasing length $(10-1000 \mathrm{bp})$ encapsulated into cubic phases formed by GMO - cationic lipids showed that the $Q_{I I}$ structure was preserved, although the $P n 3 m$ phase changed into $I m 3 m$ for higher amounts of cationic additives $(1 \leq \mathrm{mol} \% \leq 2)$ (Sarkar et al. 2020). A successful in vitro transfection of siRNA encapsulated within a GMO-cationic lipid network of a cubic structure was reported (Leal et al. 2010; Kim and Leal 2015). It is worth noting that the strands of short fragmented nucleic acids (siRNA, miRNA) are hundred times smaller than DNA, while they show much greater sensitivity for both enzymatic degradation and cationic lipids cytotoxicity. In addition to the promising utilization of cubic phases for encapsulation and delivery of short fragmented nucleic acids as mentioned above, also cubic and hexagonal structures with DNA strands containing thousands of base pairs have been reported recently (Dittrich et al. 2018; Tassler et al. 2019). The presence or formation of intracellular nonlamellar, namely cubic phases, on the DNA delivery path was revealed as an enhancing factor of transfection efficiency (Koynova et al. 2006; Tenchov et al. 2008; Safinya et al. 2014; Liskayová et al. 2019). The fusogenicity of lipoplexes plays a crucial role in transfection rate. The propensity of membranes to fuse correlates with the fraction of inverted phase-forming lipids, and its mechanism is related to the mechanism of lamellar-inverted phase transition (Siegel 1999).

Toxicity of cationic lipids and low stability of lipoplexes in the presence of serum are considered as major limitations for their use in DNA delivery (Filion and Phillips 1998; Balazs and Goodbey 2011). In addition to cationic lipoplexes, also various anionic vehicles for gene delivery have been characterized (Lee and Huang 1996; Tavitian et al. 2002; Resina et al. 2009) and found to be less toxic and useful for in vivo applications (Son et al. 2000; Lavigne et al. 2013). Anionic lipoplexes prepared due to DNA interaction with a mixture of negatively charged (DOPG or DOPS) and neutral phospholipid (DOPE) in presence of $\mathrm{Ca}^{2+}$ show low cytotoxicity and positive transfection activity in vitro on several cell lines (Patil et al. 2004; Srinivasan and Burges 2009; Barrán-Berdón et al. 2014).

In the present paper, we discuss the stability of cubic phases designed for DNA delivery, and their ability to encapsulate DNA. As DNA carriers, we took a mixture of glycerol monooleate (GMO) and negatively charged dioleoyl phosphatidylglycerol (DOPG) (Fig. 1). DNA encapsulation, from the solvent into DOPG/GMO non-lamellar phases, is mediated by the addition of $\mathrm{Ca}^{2+}$ cations, which trigger the formation of the cubic phase from the solution of DOPG/GMO unilamellar vesicles (ULVs) in excess water. Awad et al. (2005) introduced the method for transformation of large vesicles into the cubic phase. We used small angle Xray and neutron scattering (SAXS and SANS, respectively) to follow structural changes. The DNA binding is derived from UV-vis spectroscopy and the surface charge of formed particles was followed by zeta potential measurements.

\section{Material and Methods}

\section{Chemicals}


Phospholipid DOPG (1,2-dioleoyl-sn-glycero-3-phosphatidylglycerol, sodium salt) was obtained from Avanti Polar Lipids, Inc., USA. GMO (1-monooleyl-rac-glycerol) was purchased from Sigma Aldrich, USA. Lyophilized short fragmented salmon sperm DNA (sodium salt, average $\mathrm{Mr}$ of nucleotide = 308) was obtained from AppliChem $\mathrm{GmbH}$, Germany. Inorganic salts and solvents were obtained from distributors: $\mathrm{NaCl}$ (Lachema, Brno, Czech Republic), $\mathrm{CaCl}_{2}$ dihydrate (Merck, Germany), chloroform and methanol 99.5\% (Slavus, s.r.o., Slovak Republic). The chemicals were of analytical grade and used without further purification. The aqueous solutions were prepared from redistilled water or $\mathrm{D}_{2} \mathrm{O}$ of $99.9 \%$ isotopic purity (Merck, Germany) for SAXS or SANS experiments, respectively.

\section{Preparation of DNA solution}

DNA was dissolved in $150 \mathrm{mM} \mathrm{NaCl}$. The precise value of DNA concentration was determined by spectrophotometry (Hewlett-Packard 8452A diode array spectrophotometer), according to $c_{D N A}=A_{260} \cdot 4.7 \times 10^{-5}$ g. $\mathrm{mL}^{-1}$, where $A_{260}$ is the absorbance at wavelength $\lambda=260 \mathrm{~nm}$. The concentration of stock salmon sperm DNA solution was $9.35 \mathrm{mg} \cdot \mathrm{mL}^{-1}$. In the remainder of the text the DNA concentration refers to the molar concentration of DNA bases. The purity of DNA was checked by measuring the absorbance $A_{\lambda}$ at $\lambda=230,260$ and $280 \mathrm{~nm}$. The values of $A_{260} / A_{280}=1.80$ and $A_{260} / A_{230}=2.28$ indicate that the DNA solution was sufficiently pure. Fig. 2a (inset) shows UV-Vis spectrum of DNA.

The length of DNA fragments was determined by micro-capillary electrophoresis using single-channel Qsep 100 Bio-Fragment Analyzer (BiOptic Inc., Taiwan). A disposable pen-shaped cartridge was inserted and other running buffers were loaded according to the manufacturer's instructions (Kerékgyártó et al. 2012). DNA was diluted to concentration of $89.90 \mathrm{ng} . \mu \mathrm{L}^{-1}$ for analysis. The run was performed with a standard cartridge with a sample injection protocol of $4 \mathrm{kV}$ for $10 \mathrm{~s}$ and separation at $8 \mathrm{kV}$ for $160 \mathrm{~s}$ at ambient temperature. The DNA size marker $20-1000 \mathrm{bp}$ (BiOptic Inc.) was used for fragment size determination. Samples peaks were visualized using Q-Analyzer software (BiOptic Inc.). The length distribution of the fragments is shown in Fig. 2b, and in more detail, in Fig. S1 (Supplementary material). The analysis revealed a large distribution of size. The relative distribution shows that $\sim 78 \%$ of the fragments are between 20 and $300 \mathrm{bp}$, while the number of fragments containing more than $600 \mathrm{bp}$ is under $9 \%$.

\section{Preparation of samples for SAXS/WAXS experiments}

Weighted amounts of each lipid were dissolved in chloroform:methanol mixture $(3: 1 \mathrm{vol} / \mathrm{vol})$ to get solutions at precise concentration $\left(\sim 0.025 \mathrm{mg} . \mu \mathrm{L}^{-1}\right)$. DOPG/GMO mixtures were prepared by mixing aliquot volumes of lipids to get various DOPG/GMO ratios. Mixtures were carefully dried under a stream of gaseous nitrogen to create a thin lipid film spread uniformly on a glass of vials. The residues of organic solvents were removed under vacuum at $10 \mathrm{~Pa}$ for 10 hours. Each sample contained $\sim 15 \mathrm{mg}$ of dried lipid mixture, exact mass was controlled gravimetrically. Samples were prepared by hydrating dry lipid films with either only $150 \mathrm{mM}$ 
$\mathrm{NaCl}$ solution (DOPG/GMO) or addition of $\mathrm{CaCl}_{2}$ solution $(191 \mathrm{mM})\left(\mathrm{DOPG} / \mathrm{GMO}+\mathrm{Ca}^{2+}\right)$. DNA - DOPG/GMO $+\mathrm{Ca}^{2+}$ complexes were prepared similarly by hydrating the DOPG/GMO lipid with the solution of DNA at the lipid/DNA ratio 10 (mol/base) and the solution of $\mathrm{CaCl}_{2}$. The final volume of hydrating media in each sample was $650 \mu \mathrm{L}$. The molar concentration of calcium cations in each sample of DOPG/GMO $+\mathrm{Ca}^{2+}$ and DNA - DOPG/GMO $+\mathrm{Ca}^{2+}$ was $14.7 \mathrm{mM}$. Samples were prepared at ambient temperature, thoroughly homogenized by vortex mixing and at least 5 times by freezing/thawing cycles. Prior to SAXS measurements, samples were centrifuged and the sediment was transferred into a $1.5 \mathrm{~mm}$ diameter capillary tube made of borosilicate glass.

\section{Preparation of samples for SANS experiments}

DOPG/GMO mixtures were hydrated by $150 \mathrm{mM} \mathrm{NaCl}$ prepared in $\mathrm{D}_{2} \mathrm{O}$ keeping $1 \mathrm{wt} \%$ concentration. The volume of each sample was $2 \mathrm{~mL}$. The samples were homogenized by vortex and repeated freeze-thaw cycles that provided a homogeneous slightly opalescent solution, typical of dispersed lipid vesicles. Part of vesicle dispersion $(\sim 0.7 \mathrm{~mL} / \mathrm{sample})$ was filled into $2 \mathrm{~mm}$ quartz cells (Hellma, Germany) and represents the first set of samples. The rest of each DOPG/GMO dispersion was extruded through a polycarbonate filter (Nuclepore Plesanton, Canada) with pores of $100 \mathrm{~nm}$ diameter, using the LiposoFast Basic extruder (Avestin, Ottawa, Canada) fitted with two gas-tight Hamilton syringes (Hamilton, Reno, USA) as described in MacDonald et al. (1991). The samples were subjected to 51 passes through the filter at ambient temperature. The resulting solution displayed only a marginal opalescence which is typical for the dispersion of unilamellar vesicles (ULVs). The exact volume $(0.7 \mathrm{~mL})$ of each ULVs dispersion was placed in $2 \mathrm{~mm}$ quartz cells and prepared for SANS measurement (second set of samples). The third set of samples represents ULVs of DOPG/GMO with addition of $\mathrm{CaCl}_{2}$ solution. A small volume of concentrated $\mathrm{CaCl}_{2}$ solution (1M) was added to ULVs in the cell to reach $15 \mathrm{mM}$ of $\mathrm{CaCl}_{2}$. Samples were mixed by vortex and kept at ambient temperature for 4 - 6 hours before measurements.

\section{Zeta potential}

The zeta potential of DOPG/GMO vesicles was measured by the electrophoretic light scattering of particles using a particle size analyzer Litesizer 500 (Anton Paar, Austria). Liposomes at a $1 \mathrm{mg} . \mathrm{mL}^{-1}$ concentration of the lipid mixture were prepared in a $150 \mathrm{mM}$ of $\mathrm{NaCl}$ solution (as described above). DOPG/GMO vesicles were incubated in $15 \mathrm{mM}$ of $\mathrm{CaCl}_{2}$ during $\sim 1$ hour before the measurement. The ionic strength of the solution was kept constant. Polycarbonate disposable Omega cuvettes for zeta potential (Anton Paar, Austria) with volume $900 \mu \mathrm{L}$ were used for measurements at $25^{\circ} \mathrm{C}$. The zeta potential was evaluated with Kalliope software using the Smoluchowski model. For the calculation, a viscosity of $\eta=0.8903 \mathrm{mPa} \cdot \mathrm{s}$, a dielectric constant of $\varepsilon=78.37 \mathrm{Fm}^{-1}$, and a refractive index of 1.3303 were assumed. Reported average values of the zeta potential and standard deviations are obtained from 100 measurements for each sample.

Small and wide angle X-ray scattering experiments (SAXS and WAXS)

SAXS/WAXS synchrotron radiation scattering experiments were performed at the BL11-NCD-SWEET beamline, ALBA Synchrotron, Barcelona (Spain) using linearly 
polarized radiation with a wavelength $\lambda=0.12 \mathrm{~nm}$. The capillary samples were placed vertically and thermalized at $20{ }^{\circ} \mathrm{C}$ before being exposed to the radiation. An exposure time of 0.5 or $1 \mathrm{~s}$ was long enough to obtain SAXS patterns as displayed hereafter. Comparing consecutive images of the same series, we can ensure that the dose corresponding to $1 \mathrm{~s}$ of exposure time does not induce any radiation damage in the lipid mixture. CCD Quantum 210r camera was supplied by ADSC for SAXS detection. The WAXS detector was the LX255HS, which was equipped with three cooled CCD modules from Rayonix having a dynamic range of 16 bits. The mentioned exposure time was chosen in order to avoid detector saturation to maximize the signal-to-noise ratio. The raw data were normalized against the incident beam intensity. The $q$ value of the momentum transfer was calibrated using AgBh for SAXS (Huang et al. 1993) and $\mathrm{Cr}_{2} \mathrm{O}_{3}$ (certificate SRM 674b, NIST, U.S.A.) for WAXS. Scattering patterns were evaluated according to the intensity of the incident beam following an exponential model. SAXS diffraction maxima were derived by fitting each peak with a Lorentzian curve and a linear background. The lattice parameters of the cubic phases were evaluated from the slope of a plot $q_{h k l}=f\left(\sqrt{ }\left(h^{2}+k^{2}+l^{2}\right)\right)$, where $q_{h k l}$ is the position of the maximum of each peak and $h, k$, and $l$ are the Miller indices.

The WAXS pattern of all measured samples exhibited one wide, diffuse scattering peak in the range of $q \sim 10-20 \mathrm{~nm}^{-1}$, characteristic of liquid-like carbon chains of lipid molecules. Typical WAXS patterns are shown in the Supplementary material, Fig. S2.

\section{Small-angle neutron scattering experiments (SANS)}

Neutron scattering experiments were performed at the PACE spectrometer of the Orphée reactor (Laboratoire Léon Brillouin, Saclay, France). The scattered intensity $I(q)$ depends on the momentum transfer $q=(4 \pi / \lambda) \sin (\theta)$, which depends on the wavelength, $\lambda$, of the incident neutron beam and on the scattering angle $2 \theta$. It covers the domain $q$ $=0.07-3.1 \mathrm{~nm}^{-1}$. The samples were measured at two sample-to-detector distances, 4.7 and $1.2 \mathrm{~m}$, and the neutron wavelength was $\lambda=6 \AA$ (resolution $\Delta \lambda / \lambda=10 \%$ ). The temperature of the samples was $20 \pm 0.1{ }^{\circ} \mathrm{C}$. The acquisition time for a sample in each position of the detector was $30 \mathrm{~min}$. The normalized SANS intensity, $I(q)$, was obtained using the software Pasinet provided by LLB. Spectra were corrected for the incoherent background.

\section{$U V$-Vis spectroscopy}

The binding ability of DOPG/GMO mixtures for DNA was investigated using UV-vis spectroscopy (Hewlett-Packard 8452A diode array spectrophotometer). The supernatant of the samples DNA-DOPG/GMO-Ca ${ }^{2+}$ prepared for SAXS was used for the assessment of the amount of bound DNA. The amount of bound DNA was determined from the difference between the total DNA added to the sample and the unbound DNA present in the supernatant. The procedure is described in Lengyel et al. (2011), and briefly: in addition to the fraction of unbound DNA in the supernatant, light scattering lipid aggregates may also be present. The DNA absorption spectrum is superimposed on an exponentially decreasing background due to the scattering of the light by the aggregates. 
The light scattering intensity was approximated with a function $A=a \cdot \lambda^{b}$ (simplification of Rayleigh scattering), where $A$ is the absorbance at wavelength $\lambda$ and $a$ and $b$ are constants characterizing the scattering. Numerical values of the constants ( $a$ and $b$ ) were obtained by nonlinear least-squares approximation of the spectrum in the range of $\lambda=$ $330-600 \mathrm{~nm}$, i.e. out of the DNA absorption band. Afterward, the function mentioned above was extrapolated to $\lambda<330 \mathrm{~nm}$. The absorbance $A_{260}$ at $\lambda=260 \mathrm{~nm}$ was obtained after subtraction of the extrapolated scattering function from the measured spectrum. The value of $A_{260}$ was used to quantify the amount of unbound DNA in the supernatant. An example of the analysis is depicted in Fig. 2a.
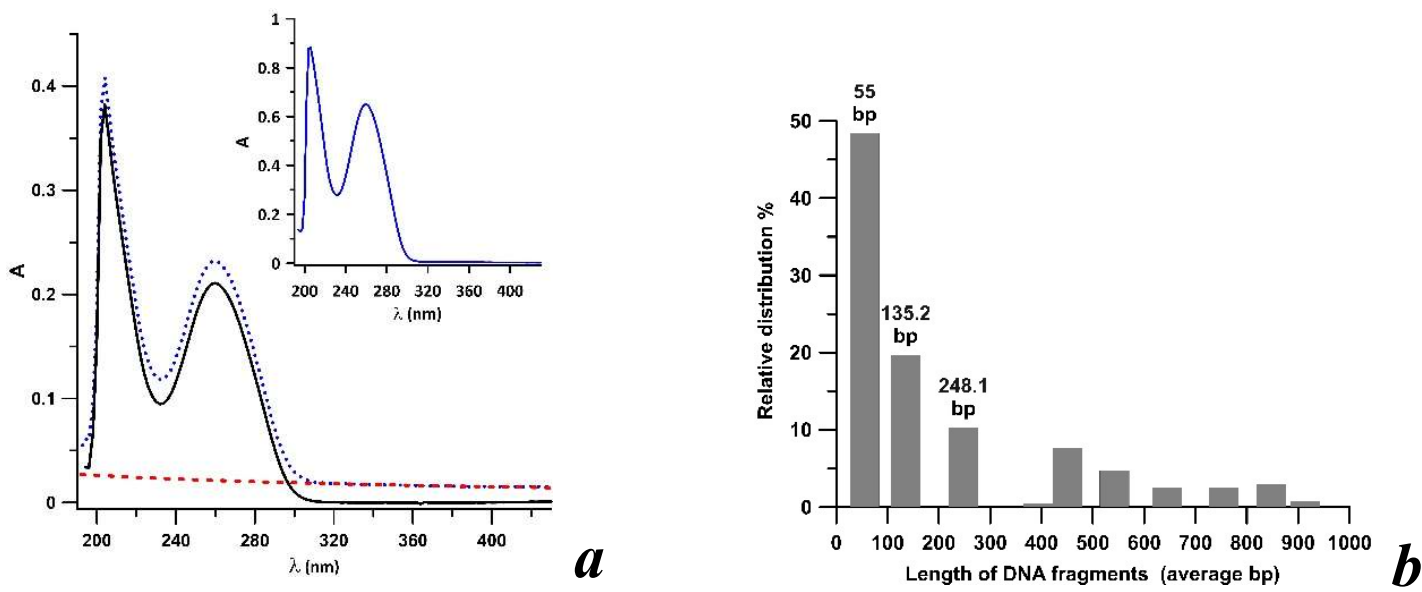

Fig. 2. a) UV-Vis spectrum of DNA from supernatant of the sample with DOPG/GMO at $26.8 \mathrm{~mol} \%$ of DOPG (lipid/DNA=10 mol/base) in $14.7 \mathrm{mM}$ of $\mathrm{CaCl}_{2}$ (blue dotted line), the extrapolated scattering function $A \lambda=a . \lambda^{b}$ (red dashed line) and the DNA absorption spectrum after the subtraction of the light scattering (black full line). For analysis see e.g. Lengyel et al. (2011). Inset: UV-Vis spectrum of short fragmented salmon sperm DNA in $150 \mathrm{mM} \mathrm{NaCl}$. b) Relative distribution of DNA fragments length (average of bp) determined by micro-capillary electrophoresis.

\section{Results and discussion}

\section{Structure of DOPG/GMO}

Fig. 3a shows selected SAXS patterns of DOPG/GMO mixtures. The content of DOPG (expressed in molar \%) in the DOPG/GMO mixtures increases from 0 (pure GMO) to $37 \mathrm{~mol} \%$. The peaks of SAXS pattern of GMO are indexed as (110), (111), (200), (211), (220), (221), (310), (311) and (222) at reciprocal spacings in the ratio $\sqrt{2}, \sqrt{ } 3, \sqrt{ } 4, \sqrt{ } 6, \sqrt{ } 8, \sqrt{ } 9, \sqrt{ } 10, \sqrt{11}$, and $\sqrt{ } 12$ and identified as a three-dimensional cubic phase of Pn3m space group (Fig. 3b). We determined the lattice parameter $a=10.04 \mathrm{~nm}$ for GMO hydrated in $0.15 \mathrm{M} \mathrm{NaCl}$ at $20{ }^{\circ} \mathrm{C}$ (Supplementary material, Fig. S3). GMO in excess of water and laboratory temperature forms a cubic phase of $P n 3 m$ space group with lattice parameter $a \sim 10 \mathrm{~nm}$ (Briggs et al. 1996; Qiu and Caffrey, 2000; Angelov et al. 2007; Brasnett et al. 2017). Negatively charged DOPG 
induces swelling of GMO cubic structure. The lattice parameter increases non-linearly with DOPG content, as displayed in Fig. 3c. DOPG/GMO with $10.8 \mathrm{~mol} \%$ of DOPG shows $a \sim 13.4$ $\mathrm{nm}$. At higher content of DOPG ( $\geq 16.1 \mathrm{~mol} \%)$, the diffraction peaks of DOPG/GMO disappear and all patterns reduce to a wide peak above the background (Fig. 3a). Additional SAXS patterns of DOPG/GMO with $16<$ DOPG $\leq 100$ mol\% are shown in Fig. S4 (Supplementary material).
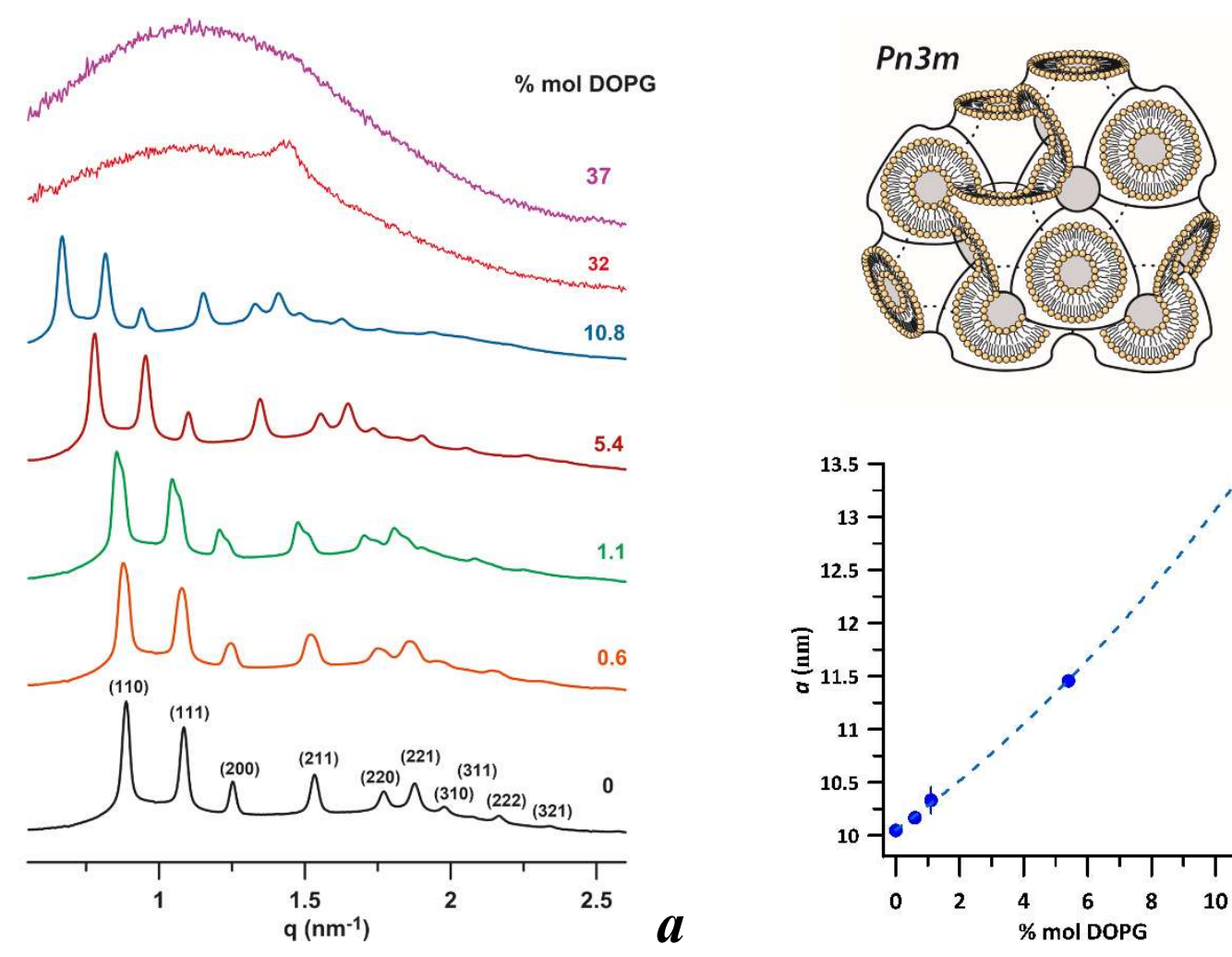

b

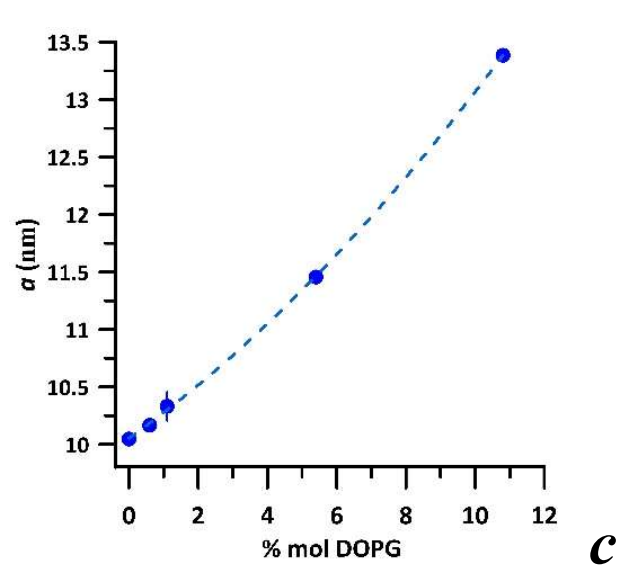

Fig. 3. a) SAXS patterns of DOPG/GMO mixtures prepared at different molar fractions of DOPG (mol \%) at $20{ }^{\circ} \mathrm{C}$. Intensities in patterns $(0-10.8 \mathrm{~mol} \% \mathrm{DOPG})$ are plotted in logarithmic scale. b) Bicontinuous cubic phase of $P n 3 m$ space group. c) Lattice parameter of DOPG/GMO cubic phase $P n 3 m$ as a function of DOPG molar fraction.

Helfrich (1973) introduced the concept of spontaneous (intrinsic) curvature in membranes. Marsh (1996) has shown that the spontaneous curvature (with radius $R_{0}$ ) for the single lipid monolayer can be predicted from the shape of molecules, which favors their specific packing. The intrinsic curvature $\left(1 / R_{0}\right)$ can be expressed as a function of the value of $V / A$.l of the lipid, where $V$ is the volume of the entire lipid molecule, $l$ is its length and $A$ is the area of the lipid head group sitting at the lipid-water interface. $R_{0}$ is defined as positive for inverted structures $(V / A . l>1)$ and negative for normal structures $(V / A . l<1)$. For planar structures, i.e. null curvature, $V / A . l=1$ and $1 / R_{0}=0$. In our experiment, DOPG is a bilayer forming lipid (large $R_{0}$ ) and GMO is non bilayer (small $R_{0}$ ) forming lipid.

The bicontinuous Pn3m cubic phase (Fig. 3b) is formed by a pair of interpenetrating but noncontacting aqueous channels separated by a single, continuous lipid bilayer. The 
structure of bicontinuous cubic phases has been described in terms of Infinite Periodic Minimal Surfaces (IPMS) (Scriven 1976) with proposed models (Luzzati et al. 1993). Assuming distinct water and lipid regions within the elementary cell, the internal structural dimensions can be calculated (Briggs et al. 1996). For a sample of known sample composition, the volume (vol $\%) \Phi_{l}$ of the lipid phase is expressed in function of the lipid length, $l$, and of the lattice parameter $a$ of the $P n 3 m$ lattice by

$$
\Phi_{l}=2 \sigma\left(\frac{l}{a}\right)+\frac{4 \pi \chi}{3}\left(\frac{l}{a}\right)^{3}
$$

where $\sigma$ and $\chi$ are the Euler constants that characterize the minimal surface for each cubic phase ( $\sigma=1.919$ and $\chi=-2$ for Pn3m cubic phase) (Turner et al. 1992). The water channel radius, $r_{w}$, can be calculated by

$$
r_{w}=\sqrt{\frac{-\sigma a^{2}}{2 \pi \chi}}-l
$$

The $r_{w}$ expressed by (2) defines the upper limit of the size of the water channel (Briggs et al. 1996; Gulik et al. 1985). The calculated lipid length, $l$, in the cubic phases (Pn3m and Ia3d), detected in the $\mathrm{GMO} /$ water system in the range $0-90{ }^{\circ} \mathrm{C}$ decreases exponentially with temperature (Briggs et al. 1996)

$$
l=1.8 e^{-0.0019}
$$

where the units of $T$ and $l$ are ${ }^{\circ} \mathrm{C}$ and nm, respectively. Applying expressions (3) and (2), with the value $a=10.04 \mathrm{~nm}$ extracted from SAXS of our fully hydrated GMO at $20^{\circ} \mathrm{C}$ and the lipid length $l=1.73 \mathrm{~nm}$, we evaluate the radius of the water channel $r_{w}=2.19 \mathrm{~nm}$.

Angelov et al. (2007) evaluated a lattice parameter $a=10.36 \mathrm{~nm}$ in the Pn3m space group for fully hydrated GMO at $20^{\circ} \mathrm{C}$, the lipid length $l=1.75 \pm 0.20 \mathrm{~nm}$ and $r_{w}=2.0 \pm 0.2 \mathrm{~nm}$. The structural parameters were derived from the fitting of SAXS intensities (Angelov et al. 2003). The values of $r_{w}$ and $l$ extracted from our measurements are in accord with these reported data.

Both the increasing fraction of DOPG in DOPG/GMO bilayer and its negative charge affect the curvature of lipid monolayers packed in the cubic structure. Due to electrostatic repulsions between DOPG headgroups, the effective area $A$ increases, thus inducing the decrease of the curvature of DOPG/GMO monolayer ( $R_{0}$ increases). The molecule of DOPG with two acyl chains is bulky compared to GMO (Fig. 1). Therefore, the elasticity of the GMO monolayer decreases with increasing fraction of DOPG. These effects result in the observed increase of the lattice parameter $a$ of $P n 3 m$ phase up to $a=13.4 \mathrm{~nm}$ at $10.8 \mathrm{~mol} \%$ of DOPG. Both the significant increase of lattice parameter and the symmetry of GMO cubic structure are sensitive to charged amphiphilic additives. Addition of less than $1 \mathrm{~mol} \%$ of negatively charged lipids (DOPG, DOPS, cardiolipin) triggers the $P n 3 m \rightarrow \operatorname{Im} 3 m$ phase transition in lipid mixtures hydrated with water or by an ethane-sulfonic acid buffer (PIPES, $10 \mathrm{mM}$ ) (Cherezov et al., 2002; Awad et al., 2005; Tyler at al., 2015). In contrast, Pn3m phase was stabilized at 0 - $30 \%$ of DOPG in presence of $1 \mathrm{M}$ of $\mathrm{NaCl}$ solution (Awad et al., 2005). Our experiments indicate that $\mathrm{NaCl}$ at $150 \mathrm{mM}$ concentration stabilizes $P n 3 m$ cubic phase up to $\sim 11 \mathrm{~mol} \%$ of DOPG in DOPG/GMO. At higher content of DOPG ( $\geq 16 \mathrm{~mol} \%$ ) all SAXS patterns show a wide peak (Fig. 3a, Fig. S4) indicating either very weak or absence of long-range order. Such patterns are congruous either with unilamellar vesicles or with the concept of $L_{3}$ phase (Porte 
1992; Lei et al. 1997), a sponge like structure formed by lipid bilayers multiconnected over macroscopic distances.

We performed small-angle neutron scattering (SANS) experiments to follow the effect of DOPG on the cubic structure of GMO hydrated by the deuterated solvent $(150 \mathrm{mM}$ of $\mathrm{NaCl}$ in $\mathrm{D}_{2} \mathrm{O}$ ), taking advantage of the contrast between the coherent neutron-scattering-length densities (SLD) of lipid bilayer and solvent. Fig. 4a shows representative SANS curves of $\mathrm{DOPG} / \mathrm{GMO}$ at $20^{\circ} \mathrm{C}$. The patterns clearly differ from reported SANS data of sponge $\mathrm{L}_{3}$ phase detected in hydrated GMO (Angelova et al. 2011). The SANS pattern of GMO with $15 \mathrm{~mol} \%$ of DOPG (red circles) shows some discontinuities or peaks (in the $q$-range between arrows) indicating the presence of different populations in the sample, likely fragments of an ordered structure. Weakly resolved peaks of low intensity do not allow specifying the structure. DOPG/GMO mixtures with higher DOPG content ( $\geq 20 \mathrm{~mol} \%$ ) show curves typical of polydisperse unilamellar vesicles. The linearity of Kratky - Porod plot of $\ln \left(I . q^{2}\right)$ vs. $q^{2}$, where $I(q)$ is the scattered intensity is "a sensitive tool" to detect possible correlations between objects such as oligo- or multi-lamellar vesicles (see e.g. Uhríková et al. 2007). Dependences depicted in Fig. 4 inset, are in spite of the scatter of experimental points linear $\left(r^{2} \sim 0.97\right)$ for DOPG/GMO with DOPG $\geq 20 \mathrm{~mol} \%$, which is not fulfilled at lower content of DOPG (15 mol\%). The experimental $I(q)$ of DOPG/GMO with DOPG $\geq 20 \mathrm{~mol} \%$ were fitted by the model of polydisperse unilamellar vesicles (with SasView software) with the aim to determine the lipid bilayer thickness.

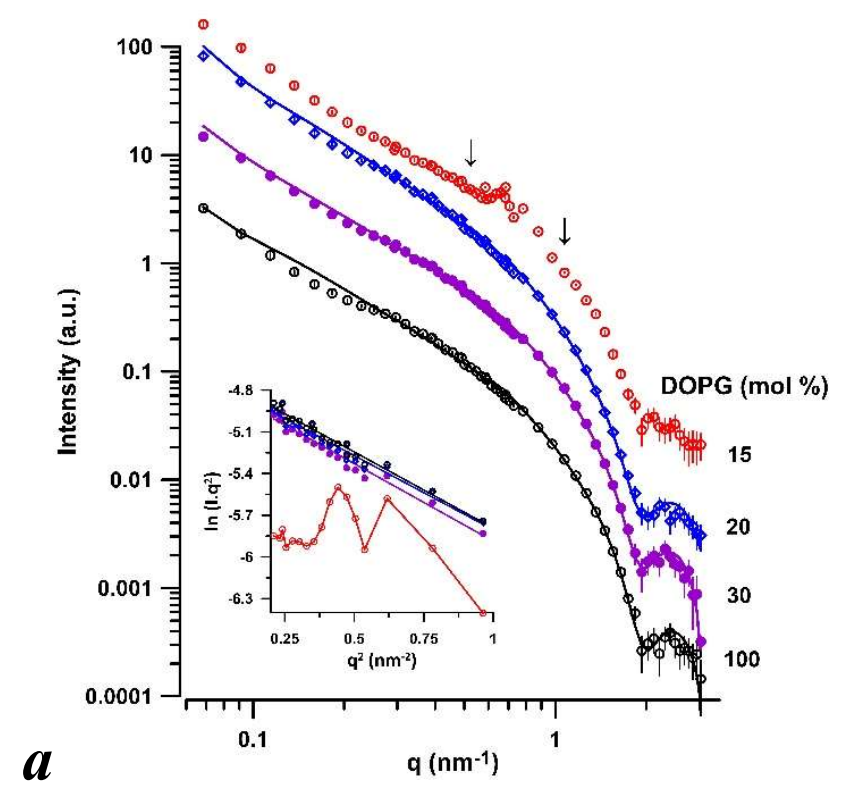

$\boldsymbol{b}$

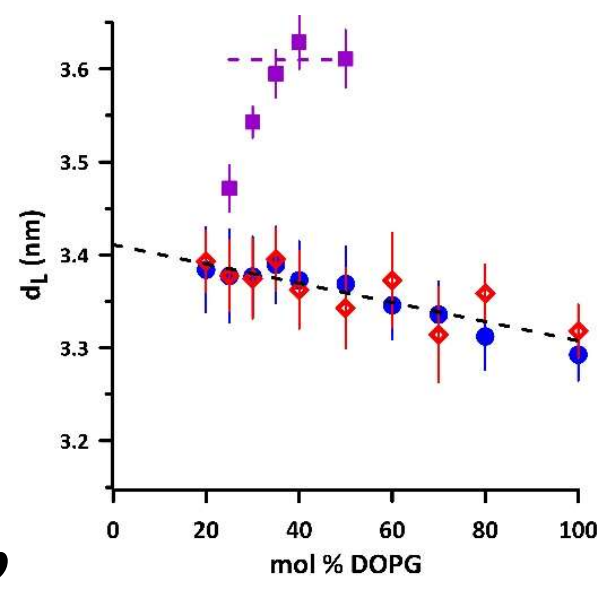

Fig. 4. a) SANS curves of DOPG/GMO mixtures (at $20{ }^{\circ} \mathrm{C}$ ) prepared at different content of DOPG (mol \%). The full lines represent the best-fit results using the model of polydisperse unilamellar vesicles. Curves are shifted along the y-axis for clarity. Inset: Kratky - Porod plot representation of scattering curves. b) The lipid bilayer thickness $\left(d_{L}\right)$ as a function of DOPG (mol \%) in DOPG/GMO vesicles (empty red diamonds); and the lipid bilayer thickness of unilamellar vesicles (ULVs) prepared by extrusion as described in Material and Methods (full 
blue circles). The dashed line represents the linear regression fit of all values. The lipid bilayer thickness $\left(d_{L}\right)$ of DOPG/GMO unilamellar vesicles in presence of $15 \mathrm{mM}$ of $\mathrm{CaCl}_{2}$ (violet squares).

The model describes a lipid vesicle as a hollow sphere with the shell of lipid bilayer thickness $\left(d_{L}\right) . I(q)$ is given by (Guinier and Fournet 1955):

$$
\begin{gathered}
I(q)=\frac{\text { scale. } \Delta \rho^{2}}{V_{\text {shell }}}\left[\frac{3 V_{l i p} j\left(q R_{2}\right)}{q R_{2}}-\frac{3 V_{\text {core }} j\left(q R_{1}\right)}{q R_{1}}\right]^{2}+b c g \\
j(x)=\frac{\sin (x)-x \cos (x)}{x^{2}}
\end{gathered}
$$

where $V_{\text {shell }}$ is the volume of the shell, scale is a scale factor, $V_{\text {lip }}$ is the total volume of the vesicle with radius $R_{2}, V_{\text {core }}$ is the volume of the water core with radius $R_{1} ; \Delta \rho$ is the contrast between the scattering length density (SLD) of lipid bilayer and the solvent and bcg is the background. The lipid bilayer thickness $d_{L}$ is given by $d_{L}=R_{2}-R_{1}$. Polydispersity was included in the fit by convolution with a Schulz distribution of diameters. The instrumental resolution, $\Delta q / q \cong 10 \%$ is taken into account.

Each DOPG/GMO mixture was measured twice: vesicles formed spontaneously due to the disintegration of the GMO cubic phase and, after the mixture extrusion through polycarbonate filters with pore diameter $100 \mathrm{~nm}$. Results were almost identical, the values of $d_{L}$ coinciding within fitting uncertainties. Fig. $4 \mathrm{~b}$ depicts the dependence of $d_{L}$ on the concentration of DOPG $(\mathrm{mol} \%) . d_{L}$ decreases smoothly with increasing DOPG molar fraction, $d_{L}=-0.001 . \mathrm{mol} \% \mathrm{DOPG}+3.41\left(\mathrm{r}^{2}=0.896\right)$. We find $d_{L}=3.39 \pm 0.04 \mathrm{~nm}$ for $20 \mathrm{~mol} \%$ of DOPG in DOPG/GMO. The extrapolation of the linear dependence to $0 \mathrm{~mol} \%$ of DOPG gives $d_{L}=3.41 \pm 0.04 \mathrm{~nm}$, which fits well with the thickness, $2 l$, of two GMO monolayers, $d_{L}=2 l=$ $3.46 \mathrm{~nm}$. On the other hand, the lipid bilayer thickness $d_{L}=3.31 \pm 0.05 \mathrm{~nm}$ is obtained for pure DOPG. The obtained value (within the error) is $\sim 0.2-0.3 \mathrm{~nm}$ smaller than the DOPG lipid bilayer thickness $d_{B}=3.63 \pm 0.07 \mathrm{~nm}$ reported by Pan et al. (2012). The difference between the values may result from the difference between the models applied to evaluate the lipid bilayer thickness. In our analysis, lipid and water represent two discrete separated layers (Luzzati's approach). The thickness $d_{B}$ is extracted from the scattering length density profiles (SDP) taking data from neutron and X-ray scattering techniques combined with molecular dynamic simulations expressing the volume probability distributions of the lipid molecular components and water molecules in the bilayer (Kučerka et al. 2008). The range $0 \leq \mathrm{mol} \% \leq 40$ of DOPG in DOPG/GMO mixtures is discussed in the next paragraphs. In this range, the change of the bilayer thickness $\Delta d_{L}=d_{L G M O}-d_{L 40 \% D O P G}=0.04 \mathrm{~nm}$, where $d_{L G M O}$ and $d_{L 40 \% D O P G}$ is the bilayer thickness of GMO and DOPG/GMO with $40 \mathrm{~mol} \%$ of DOPG, respectively, is at the level of experimental accuracy. The monolayer thickness $l=d_{L} / 2=1.70 \mathrm{~nm}$ can be considered as constant, with an uncertainty $\pm 0.10 \mathrm{~nm}$.

Fig. $4 \mathrm{~b}$ shows that DOPG molecules have very little effect on the thickness of the lipid bilayer of DOPG/GMO mixtures. However, DOPG changes significantly the curvature of water channels of Pn3m cubic phase in DOPG/GMO system. Assuming a constant lipid monolayer thickness $l \sim 1.7 \mathrm{~nm}$, the change of the radius of water channels of $P n 3 m$ phase can be calculated using equation (2). The lattice parameter $a$ increases from $10.04 \mathrm{~nm}$ to $13.40 \mathrm{~nm}$ 
with the DOPG fraction changing from 0 to $10.8 \mathrm{~mol} \%$, respectively. The increase of DOPG content to $10.8 \mathrm{~mol} \%$ dilates the water channels of $P n 3 m$ phase, changing their radius $r_{w}$ from 2.19 to $\sim 3.50 \mathrm{~nm}$.

SANS experiments show that DOPG/GMO mixtures with DOPG $>15 \mathrm{~mol} \%$ form unilamellar vesicles in $150 \mathrm{mM}$ of $\mathrm{NaCl}$. We intend to examine how DNA strands fit into the water channels of the cubic structure. Calcium is used to mediate the binding of DNA polyanion to DOPG/GMO. First, we investigate the effect of $\mathrm{Ca}^{2+}$ on DOPG/GMO mixtures focusing on the concentration range DOPG $>15 \mathrm{~mol} \%$.

\section{Structure of GMO/DOPG $+\mathrm{Ca}^{2+}$ mixtures}

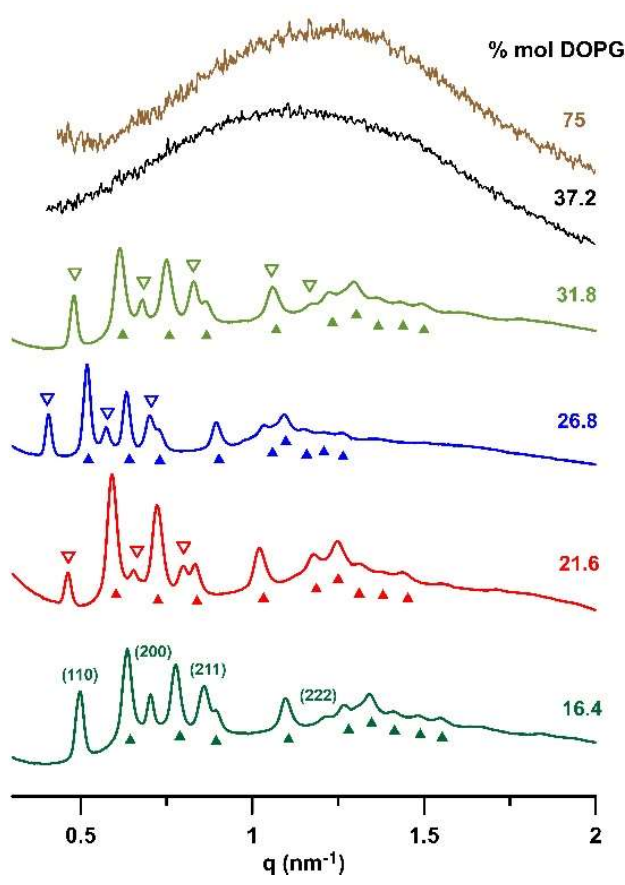

Fig. 5. SAXS patterns of GMO/DOPG mixtures in presence of $14.7 \mathrm{mM}$ of $\mathrm{Ca}^{2+}$. Full triangles flag peaks of $P n 3 m$ cubic phase. Peak assignment $(h k l)$ of $I m 3 m$ phase (empty triangles) is displayed in the bottom pattern. In the cases of cubic phases, the intensity is plotted in logarithmic scale.

Fig. 5 shows SAXS patterns of DOPG/GMO mixtures with DOPG $>16 \mathrm{~mol} \%$ in presence of $14.7 \mathrm{mM}$ of $\mathrm{CaCl}_{2}$. The $\mathrm{Ca}^{2+}$ concentration was kept constant in all samples. SAXS shows structures with long-range order up to $\sim 32 \mathrm{~mol} \%$ of DOPG. For higher concentrations, patterns reduce to a broad peak, as depicted in Fig. 5. The peaks were identified as a superposition of two cubic phases. Peaks at reciprocal spacings in the ratio $\sqrt{2}, \sqrt{3}, \sqrt{4}, \sqrt{6}$, $\sqrt{ } 8, \sqrt{ } 9, \sqrt{ } 10, \sqrt{ } 11$ and $\sqrt{ } 12$ correspond to $P n 3 m$ phase (full triangles), and peaks with spacings in the ratio $\sqrt{2}, \sqrt{ } 4, \sqrt{ } 6$ and $\sqrt{ } 12$ were indexed as $(110),(200),(211)$ and (222) reflections of the Im $3 m$ phase (empty triangles). The lattice parameter $a$ was determined from the slope of the linear dependence of the position of peaks maxima $q_{(h k l)} v s . \quad \sqrt{ }\left(h^{2}+k^{2}+l^{2}\right)\left(r^{2}>0.9999\right)$ (Supplementary material, Fig. S5). The values of lattice parameters of phases detected in DOPG/GMO $-\mathrm{Ca}^{2+}$ with increasing DOPG content (mol\%) are summarized in Table 1. 
In an IPMS representation, the $P n 3 m$ and $\operatorname{Im} 3 m$ phases correspond to the diamond $(D)$ and primitive $(P)$ surfaces, respectively. In the states of cubic-cubic coexistence, the unit cell dimensions $(a)$ of these phases should satisfy the ratio $a_{I m 3 m} / a_{P n 3 m}=1.28$ according to the Bonnet transformation between their surfaces (Hyde et al. 1984; Templer 1998). It is interesting to point out that the Im $3 m$ and Pn $3 m$ phases detected in the DOPG/GMO $-\mathrm{Ca}^{2+}$ system comply with this IPMS representation.

The addition of the $\mathrm{Ca}^{2+}$ solution to the DOPG/GMO mixture causes two effects: the fusion of DOPG/GMO vesicles and changes of the membrane curvature. We identified the coexistence of two cubic phases in the concentration range $\sim 16-32 \mathrm{~mol} \%$ of DOPG in DOPG/GMO mixtures in presence of $\sim 15 \mathrm{mM}$ of $\mathrm{CaCl}_{2} \cdot \mathrm{Ca}^{2+}$ cations reduce the lateral area per lipid $(A)$ by shielding electrostatic repulsion between negatively charged DOPG molecules that in turn allows renewing non-lamellar structures at DOPG fraction $>10.8 \mathrm{~mol} \%$ (Figure 3). Table 1 shows DOPG/ $\mathrm{Ca}^{2+}$ molar ratios expressed in respect to the total amount of $\mathrm{Ca}^{2+}$ ions in the sample. DOPG/ $\mathrm{Ca}^{2+}$ increases in the range $0.7-1.1$ with DOPG fraction up to 31.8 $\mathrm{mol} \%$. The SAXS pattern of mixtures at content of DOPG $\geq 37.2 \mathrm{~mol} \%\left(\mathrm{DOPG} / \mathrm{Ca}^{2+} \geq 1.3 \mathrm{in}\right.$ our system) do not show the presence of any ordered structure, e.g., a lamellar or hexagonal phase. We cannot exclude the presence of structures without long-range order causing the increase of the background and weaker peaks of higher orders of $Q_{I I}$ phases. The patterns suggest the transformation of vesicles directly to the cubic phases.

Several mechanisms of structural reorganization underlining a key role of $\mathrm{Ca}^{2+}$ concentration were proposed and discussed by Awad et al. (2005) and Yaghmur et al. (2008, 2011). The condensing effect of $\mathrm{Ca}^{2+}$ at the level of polar headgroups up to affecting the acyl chains packing was previously corroborated experimentally and by molecular simulations e.g. (MacDonald and Seelig 1987; Garidel et al. 1997; Arseneault and Lafleur 2006; Filippov et al. 2009; Melcrová et al. 2016). Its quantitative impact on the structural parameters of the bilayer, namely the lipid bilayer thickness and lateral area A, is not uniform. In addition to the chemical nature, state of the lipid, hydration and temperature it depends also on the cation ${ }^{2+}$ concentration (Melcrová et al. 2016; Uhríková et al. 2008; Kučerka et al. 2017; 2021).

Table 1 Lattice parameters of $P n 3 m$ and $\operatorname{Im} 3 m$ cubic phases detected in DOPG/GMO - $\mathrm{Ca}^{2+}$ for increasing fractions of DOPG (mol \%). Values DOPG/Ca ${ }^{2+}$ express the ratio of total amounts of DOPG and $\mathrm{Ca}^{2+}$, respectively, in the sample.

\begin{tabular}{|c|c|c|c|c|}
\hline $\begin{array}{l}\% \text { mol } \\
\text { DOPG }\end{array}$ & $\frac{\text { mol DOPG }}{\mathrm{mol} \mathrm{Ca}^{2+}}$ & $\begin{array}{l}\text { Pn3m } \\
a(\mathrm{~nm})\end{array}$ & $\begin{array}{l}\mathrm{Im} 3 \mathrm{~m} \\
a(\mathrm{~nm})\end{array}$ & $\frac{a_{I m 3 m}}{a_{P n 3 m}}$ \\
\hline 16.4 & 0.7 & $14.07 \pm 0.01$ & $17.97 \pm 0.05$ & 1.28 \\
\hline 21.6 & 0.8 & $15.13 \pm 0.02$ & $19.26 \pm 0.03$ & 1.27 \\
\hline 26.8 & 1.0 & $17.24 \pm 0.03$ & $21.92 \pm 0.04$ & 1.27 \\
\hline 31.8 & 1.1 & $14.57 \pm 0.02$ & $18.64 \pm 0.03$ & 1.28 \\
\hline
\end{tabular}


We have performed additional SANS experiments intending to test the conversion of unilamellar vesicles into a cubic structure in DOPG/GMO induced by $15 \mathrm{mM}$ of $\mathrm{Ca}^{2+}$. Fig. 6 shows the scattering curves. We identify the conversion vesicle $\rightarrow$ cubic phase triggered by $\mathrm{CaCl}_{2}$ in ULV's dispersion of DOPG/GMO with $25 \leq \mathrm{mol} \% \mathrm{DOPG} \leq 50$. In addition to the scattering of unilamellar vesicles, we observe discontinuities in the low $q$ range $\left(q<0.4 \mathrm{~nm}^{-1}\right)$ attributed to peaks of a cubic phase. The analysis of low $q$-range of SANS curve of DOPG/GMO with $25 \mathrm{~mol} \%$ of DOPG detected peaks at spacing $\sqrt{2}, \sqrt{4}$ and $\sqrt{6}$ of $\operatorname{Im} 3 m$ cubic phase with lattice parameter $a=34.9 \pm 0.2 \mathrm{~nm}$ (Fig. S6, Supplementary material). The value of $a$ is bigger in comparison to that detected for $\operatorname{Im} 3 m$ phase in DOPG/GMO mixture with 25 mol\% DOPG examined by SAXS (Table 2). The cubic structure re-building in the DOPG/GMO-Ca ${ }^{2+}$ system depends on many parameters (concentration of each component, temperature, time, mixing etc.) as it follows from kinetic studies (Awad et al. 2005, Yaghmour et al. 2008 and 20011). In this case, the molar ratio $\mathrm{DOPG} / \mathrm{Ca}^{2+}=0.35$ as well as the length of incubation time of DOPG/GMO in $\mathrm{CaCl}_{2}$ solution play a key role. Peaks of a cubic phase are less well resolved, nevertheless evident, also in scattering patterns of the mixtures with 35 $\leq \mathrm{DOPG} \leq 50 \mathrm{~mol} \%$. The low $q$-range of SANS curves was fitted by a model of unilamellar vesicles (described above) to determine the lipid bilayer thickness $d_{L}$. The obtained data are shown in Fig. $4 \mathrm{~b}$ (full squares). $d_{L}$ slightly increases with the DOPG fraction, reaching $d_{L}=$ $3.61 \pm 0.02 \mathrm{~nm}$ at DOPG $\geq 35 \mathrm{~mol} \%$. Fig. 6 inset depicts $d_{L}$ as a function of DOPG/Ca ${ }^{2+}$ molar ratio. We attribute this increase of $d_{L}$ to condensing effects of $\mathrm{Ca}^{2+}$ in DOPG/GMO bilayers. Assuming the monolayer thickness $l=d_{L} / 2=1.81 \mathrm{~nm}$, allow us to express the radius of water channels in cubic phases using eq. (2). We found $r_{w}$ ranging between $\sim 3.7-4.9 \mathrm{~nm}$ (with an uncertainty $\pm 0.1 \mathrm{~nm}$ ) in both phases $(\sigma=1.919$ and $2.345 ; \chi=-2$ and -4 for Pn3m and $\operatorname{Im} 3 m$, respectively) (Turner et al. 1992).

SANS curves of DOPG/GMO $-\mathrm{Ca}^{2+}$ mixtures with DOPG $\geq 60 \mathrm{~mol} \%$ are shown in Fig. S7 (Supplementary material). High content of DOPG (DOPG/GMO $\geq 1.5 \mathrm{~mol} / \mathrm{mol}$ ) affects the curvature of the bilayer. DOPG molecules with two acyl chains and their area per lipid $\sim 2.5$ times larger than GMO (Pan et al. 2012; Angelov at al. 1999) promote lamellar packing $\left(R_{0}\right.$ increases). Indeed, the patterns differ from those shown in Fig. 6. We do not observe any peaks in the low $q$-range. A peak observed at $q \sim 1.1 \mathrm{~nm}^{-1}$ indicates a structure with the periodicity $d$ $\sim 2 \pi / q=5.7 \mathrm{~nm}$. We attribute it to a phase formed by DOPG/GMO - $\mathrm{Ca}^{2+}$ multilamellar vesicles. Therefore, the model of unilamellar vesicles is not plausible for the analysis of the neutron scattering curves of DOPG/GMO $-\mathrm{Ca}^{2+}$ with DOPG $\geq 60 \mathrm{~mol} \%$.

$\mathrm{Ca}^{2+}$ ions screen the repulsion between DOPG's what in turn promotes structural reorganization. Isothermal titration experiments have shown that the binding saturation of $\mathrm{Ca}^{2+}$ ions in bilayers of PC/PG (and DOPC/DOPS) vesicles is reached at electroneutrality which was found at molar ratio $\mathrm{PG} / \mathrm{Ca}^{2+} \sim 2$ in a solution at low ionic strength (Arseneault and Lafleur 2006; Graber et al. 2017). However, the proportion of negatively charged lipid within the membrane as well as the bulk $\mathrm{NaCl}$ concentration have a significant impact on the fraction of $\mathrm{Ca}^{2+}$ associated with the membrane. While the presence of negatively charged lipid can enhance the surface concentration of $\mathrm{Ca}^{2+}$ up to several orders with respect to the bulk concentration, high content of salts in the solution screen charges which leads to a decrease in the enrichment of $\mathrm{Ca}^{2+}$ near the membrane. Thus, the point of saturation/electroneutrality 
differs from that predicted for nominal charges (Arseneault and Lafleur 2006; Seelig 1990; Ekerdt and Papahadjopoulos 1982; Sinn et al. 2006; Pullmannová et al. 2012). The knowledge of the DOPG/GMO surface charge in a $\mathrm{CaCl}_{2}$ solution in our experimental conditions can help to assess the $\mathrm{Ca}^{2+}$ effect. Electrophoresis does not reveal the direct surface potential, but the electrical potential at the shear plane $(\sim 0.2 \mathrm{~nm})$, i.e. the zeta potential $(\xi)$. However, its values reflect the surface potential of vesicles in solution (Huster et al. 2000). Fig. 6b depicts the dependence of zeta potential of DOPG/GMO vesicles in $150 \mathrm{mM}$ of NaCl. As expected, values of $\xi$ decrease with increasing DOPG fraction, reaching a constant value $\xi=-48.9 \pm 0.6 \mathrm{mV}$ for DOPG $\geq 50 \mathrm{~mol} \%$. Zeta potential measurements intended to assess $\mathrm{Ca}^{2+}$ binding to negatively charged DOPG/GMO vesicles and as such we performed measurements in a short time span after ULV's preparation $(<2.5$ hours) to minimize the aggregation effect leading to formation of $Q_{I I}$ phases. $15 \mathrm{mM}$ of $\mathrm{CaCl}_{2}$ screens surface charges of DOPG, and zeta potential increases by $\sim+30 \mathrm{mV}$. However, the surface charge of vesicles remains negative. The nominal charge ratio DOPG/ $\mathrm{Ca}^{2+}(\mathrm{mol} / \mathrm{mol})$ expressed from total amounts of DOPG and $\mathrm{Ca}^{2+}$, respectively, in the sample ranges between $\sim 0.2-1.1$ (Tab. 1 and Fig. 6, inset). These values indicate the excess of $\mathrm{Ca}^{2+}$ in our samples (supposing neutrality at DOPG: $\mathrm{Ca}^{2+}=2$ $\mathrm{mol} / \mathrm{mol}$ ) and evidently do not reflect real surface charge. The obtained zeta potential data underline the role of ionic strength in $\mathrm{Ca}^{2+}$ binding, however the structural specificity resulting from DOPG/GMO membrane can play an important role for $\mathrm{Ca}^{2+}$ binding as well. The complexity of $\mathrm{Ca}^{2+}$ binding to lipid bilayers of different compositions were discussed recently in Melcrová et al. (2016); Kučerka et al. (2021) (and references therein).
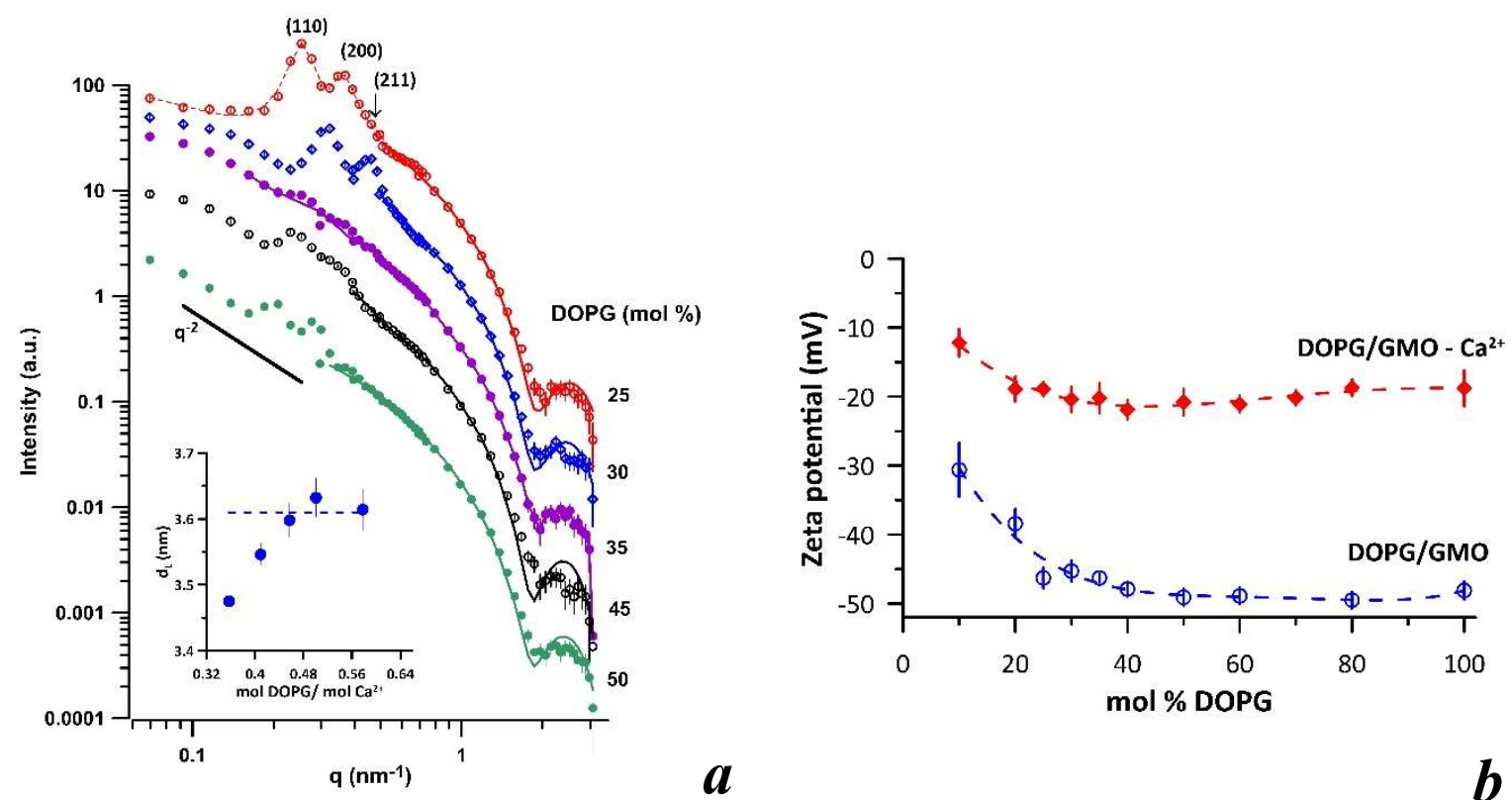

$\boldsymbol{a}$

Fig. 6. a) SANS curves of unilamellar vesicles of DOPG/GMO prepared by extrusion and incubated in $15 \mathrm{mM}$ of $\mathrm{CaCl}_{2}$. Full lines represent the best fit applying a model of ULV's in $q$ -range $>0.45 \mathrm{~nm}^{-1}$. Low $q$ - range was fitted as a superposition of three Lorentzians and 
exponentially decreasing background (dashed line). The black straight line shows the $q^{-2}$ decay behaviour characteristic for a bilayer form factor. Inset: The lipid bilayer thickness $d_{L}$ derived from ULV's and expressed as a function of DOPG/ $\mathrm{Ca}^{2+}$ molar ratio in DOPG/GMO $-\mathrm{Ca}^{2+}$ with $25 \leq$ DOPG mol $\% \leq 50$. Values DOPG/ $/ \mathrm{Ca}^{2+}$ express the ratio of total amounts of DOPG and $\mathrm{Ca}^{2+}$, respectively, in the sample. b) Zeta potential of ULV's vesicles of DOPG/GMO (blue circles) and DOPG/GMO in $15 \mathrm{mM}$ of $\mathrm{CaCl}_{2}$ (red diamonds) as a function of DOPG mol\%. Zeta potential measurements were performed in a time span $<2.5$ hours after ULV's preparation to minimize the effect of aggregation.

\section{Structure of DNA - GMO/DOPG + $\mathrm{Ca}^{2+}$ mixtures}

The accommodation of DNA into the aqueous channels of cubic phases implies two problems: the radius of the water channels must be large enough to fit a hydrated DNA strand of diameter $\sim 2.6 \mathrm{~nm}$ (Mandelkern et al. 1981; Koltover et al. 1998), and the bendability of DNA strands. Our experiments show that DOPG modulates the radius of water channels in cubic phases. In addition, we utilized the transformation vesicle $\rightarrow$ cubic phase induced by $\mathrm{Ca}^{2+}$ for DNA binding. In the following experiment, hydrated DOPG/GMO mixtures prepared at DOPG $>15$ mol\% were homogenized and consecutively mixed and incubated with $\mathrm{DNA}+\mathrm{CaCl}_{2}$.
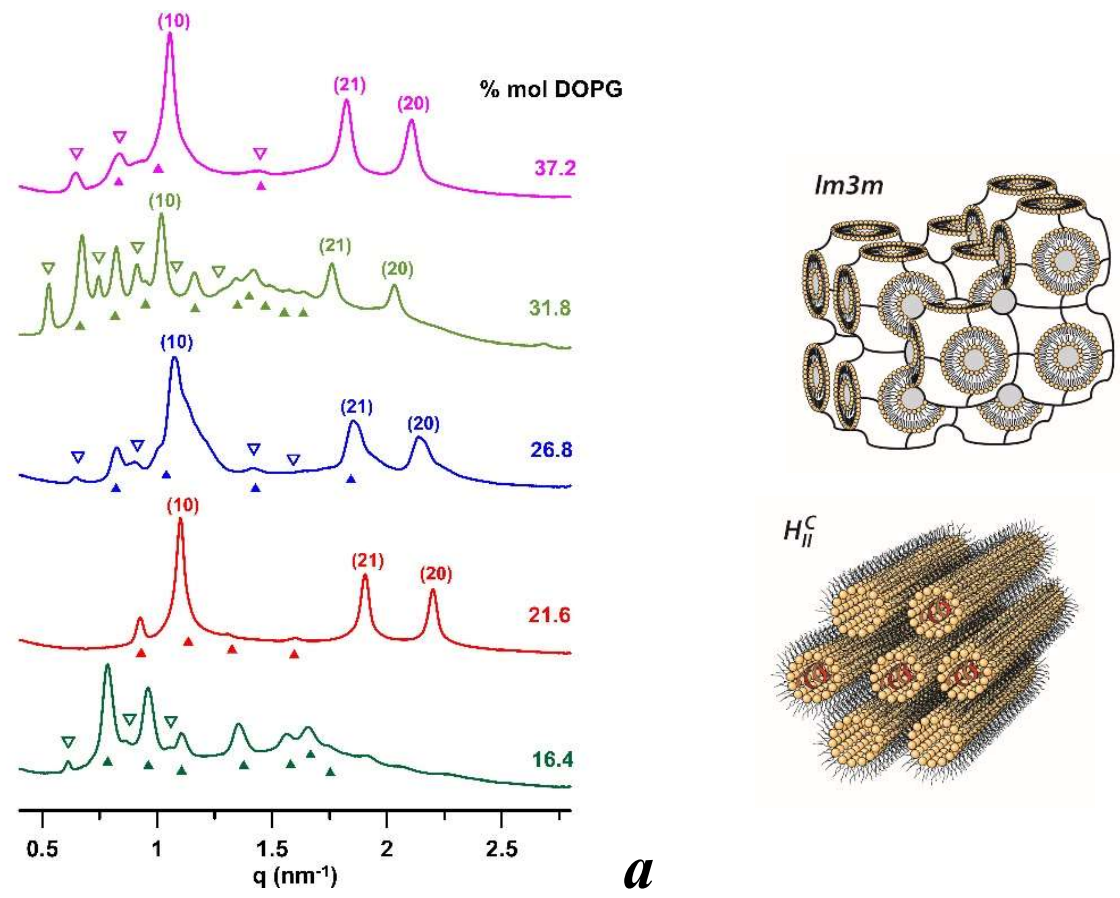

Fig. 7. a) SAXS patterns of DNA - DOPG/GMO mixtures with $16.4 \leq \mathrm{DOPG}$ mol $\% \leq 37.2$, lipid:DNA $=10 \mathrm{~mol} /$ base in presence of $14.7 \mathrm{mM}$ of Ca $^{2+}\left(20^{\circ} \mathrm{C}\right)$ Full and empty triangles flag peaks of $P n 3 m$ and $\operatorname{Im} 3 \mathrm{~m}$ cubic phase, respectively. Peaks of $H_{I I}$ phase are indexed with $(h k)$ maxima. Intensities are plotted in logarithmic scale. b) Bicontinuous cubic phase of $\operatorname{Im} 3 m$ space group and condensed inverted hexagonal phase $H_{I I}{ }^{C}$. 
Fig. 7 shows diffractograms of structures occurring in mixtures DNA-DOPG/GMO-Ca ${ }^{2+}$ with a DOPG content $16.4 \leq \mathrm{mol} \% \leq 37.2$. Two cubic phases, of $P n 3 m$ and $I m 3 m$ space group, are identified in the mixture with $16.4 \mathrm{~mol} \%$ of DOPG. The structure is similar to the system of DOPG/GMO-Ca ${ }^{2+}$. Instead, the DNA binding modulates the structure of complexes prepared at higher content of DOPG: a two-dimensional hexagonal phase $H_{I I}$ is the dominant phase for DOPG/GMO containing $21.6 \mathrm{~mol} \%$ of DOPG, in $\mathrm{Ca}^{2+}$ solution. Peaks with $(h k)$ maxima are observed at reciprocal spacing $1, \sqrt{ } 3$, and 2 with the lattice parameter $a_{H}$ following $q(h k)=\left(4 \pi / a_{H} \cdot \sqrt{3}\right) \cdot \sqrt{ }\left(h^{2}+k^{2}-h k\right)$, where $h$ and $k$ are Miller indices. The SAXS pattern also shows a few additional peaks at spacing $\sqrt{ } 2, \sqrt{ } 3, \sqrt{ } 4$, and $\sqrt{6}$ identified as reflections of the $P n 3 m$ space group. The pattern of the mixture DNA-DOPG/GMO-Ca ${ }^{2+}$ with $26.8 \mathrm{~mol} \%$ of DOPG shows the superposition of three phases. Peaks of the hexagonal phase $H_{I I}$ are superposed to peaks assigned to cubic phases $P n 3 m$ and $\operatorname{Im} 3 m$. Note, the right-hand side asymmetry of the $H(10)$ peak, and less evident right-hand side shoulder of $H(21)$ and $H(20)$ indicate either the presence of two hexagonal phases with slightly different lattice parameters or/and an overlap with peaks of cubic phases. The pattern of the mixture DNA-DOPG/GMO-Ca ${ }^{2+}$ with $31.8 \mathrm{~mol} \%$ of DOPG is well described by the three structures. Fig. S8 (Supplementary material) shows an example of evaluation of the lattice parameters of each phase. They are summarized in Table 2 . The lattice parameters of cubic phases are smaller than those of DOPG/GMO $-\mathrm{Ca}^{2+}$ listed in Table 1. The changes of lattice parameters are depicted in Fig. S9 (Supplementary material). The cubic phases shrink due to DNA binding mediated by $\mathrm{Ca}^{2+}$. However, the two cubic phases change their dimensions synchronously as the ratio of their lattice parameters $a_{I m 3 m} / a_{P n 3 m}$ is close to the Bonnet relationship ( $\left.a_{I m 3 m} / a_{P n 3 m}=1.28\right)$. Supposing the constant length $l \sim 1.81 \mathrm{~nm}$ of DOPG/GMO-Ca ${ }^{2+}$ monolayer, the radii of the water channels of the cubic phases are $r_{w} \sim$ $1.9-3.4 \mathrm{~nm}$, meaning a space large enough for hydrated DNA strands. $H_{I I}$ phase is dominant in all mixtures with DOPG $\geq 21.6 \mathrm{~mol} \%$. The lattice parameter, $a_{H}$, of lipid tubules arranged in hexagonal symmetry changes slightly with DOPG content, $a_{H} \sim 6.6-7.1 \mathrm{~nm}$. From the geometry of hexagonally packed tubules, the approximate radius of the water core is given by $r_{H w}=\left(a_{H}-2 l\right) / 2$. Application to the range of $a_{H}$, yields $r_{H w} \sim 1.5-1.7 \mathrm{~nm}$, a value that fits to accommodate hydrated DNA with radius $r_{D N A} \sim 1.3 \mathrm{~nm}$. The inverted condensed hexagonal phase $H_{I I}{ }^{C}$ with $r_{H w} \sim 1.4 \mathrm{~nm}$ was reported as a structure with DNA strands inserted in the tubules formed by a mixture of cationic and neutral lipid molecules, arranged in hexagonal symmetry (Koltover et al. 1998). Our short analysis shows that lattice parameters of all detected non-lamellar phases $\left(H_{I I}, P n 3 m\right.$ and $\left.I m 3 m\right)$ are large enough to accommodate DNA strands in their water channels. The transition of bicontinuous $I a 3 d$ cubic phase into $H_{I I}$ induced by short fragmented DNA was previously reported (Leal et al. 2013). The authors hypothesized that stacked DNA fragments longer than the cubic unit cell length disfavor the highly curved channels of $Q_{I I}$ and thus stimulate the $Q_{I I} \rightarrow H_{I I}$ phase transition.

Table 2 The lattice parameters of the hexagonal $H_{I I}$ phase and cubic phases (Pn3m and $\operatorname{Im} 3 m$ ) detected in DNA - DOPG/GMO - $\mathrm{Ca}^{2+}$ mixtures

$\begin{array}{ccccc}\text { \% mol } & H_{I I} & P n 3 m & I m 3 m & a_{I m 3 m} \\ \text { DOPG } & a_{H}(\mathrm{~nm}) & a(\mathrm{~nm}) & a(\mathrm{~nm}) & \frac{a_{P n 3 m}}{}\end{array}$




\begin{tabular}{ccccc}
\hline $\mathbf{1 6 . 4}$ & & $11.36 \pm 0.01$ & $14.54 \pm 0.05$ & 1.28 \\
\hline $\mathbf{2 1 . 6}$ & $6.59 \pm 0.02$ & $9.61 \pm 0.01$ & & \\
\hline $\mathbf{2 6 . 8}$ & $6.77 \pm 0.03$ & $10.76 \pm 0.03$ & $13.92 \pm 0.04$ & 1.29 \\
\hline $\mathbf{3 1 . 8}$ & $7.14 \pm 0.03$ & $13.25 \pm 0.05$ & $16.93 \pm 0.03$ & 1.28 \\
\hline $\mathbf{3 7 . 2}$ & $6.89 \pm 0.03$ & $10.96 \pm 0.20$ & $13.67 \pm 0.07$ & 1.23 \\
\hline
\end{tabular}

\section{DNA binding}

Cubic phases of lipid systems are associated with high viscosity. Macroscopically, in aqueous solutions, they form transparent separated gel-like particles frequently attached to the less hydrophilic surface of the sample container. Lipid mixtures or DNA-lipid complexes of $H_{I I}$ structure form macroscopically a fine white precipitate. In our experiments, part of DNA was trapped in the formed lipid structures. Instead, unbound DNA remains in the aqueous medium of supernatant easily separable by centrifugation (see Material and Methods). Fig. 8 shows the amount of DNA (in wt $\%$ ) bound in non-lamellar structures of DOPG/GMO $-\mathrm{Ca}^{2+}$ mixtures with DOPG content $16.4 \leq \mathrm{mol} \% \leq 37.2$. The $\mathrm{Ca}^{2+}$ concentration was the same in all samples. Our analysis shows that DNA binding varies between $\sim 7$ to $20 \mathrm{wt} \%$ of total DNA in the sample, which represents $70-200 \mu \mathrm{g}$ of nucleic acid trapped in $\sim 15 \mathrm{mg}$ of lipid mixture forming non-lamellar structures. Interestingly, the amount of bound nucleic acid does not show monotonic dependence on DOPG content. We can discriminate the structures identified in DNA-DOPG/GMO $-\mathrm{Ca}^{2+}$ mixtures (Fig. 7). The relative intensity of the peaks (their area) is proportional to the amount of each phase present in the volume of the sample. Therefore, the relative amounts of each phase can be evaluated. In the mixture at $16.4 \mathrm{~mol} \%$ of DOPG, the Pn $3 m$ cubic phase is dominant (Fig. 7). The $\operatorname{Im} 3 m$ phase is also present in this mixture, but in a much smaller amount. Fig. 8 shows that the highest amount $(\sim 20 \%)$ of bound DNA is observed in the mixture with $16.4 \mathrm{~mol} \%$ of DOPG, for which the Pn $3 m$ cubic phase is dominant. $H_{I I}$ phase (or condensed $H_{I I}{ }^{C}$ ) is present in all mixtures with DOPG $\geq 21.6 \mathrm{~mol} \%$. Actually, the $H_{I I}$ phase is the dominant structure in the mixture with $21.6 \mathrm{~mol} \%$ of DOPG. A few additional peaks in the SAXS pattern were identified as Pn3m cubic phase, although in tiny quantity. 


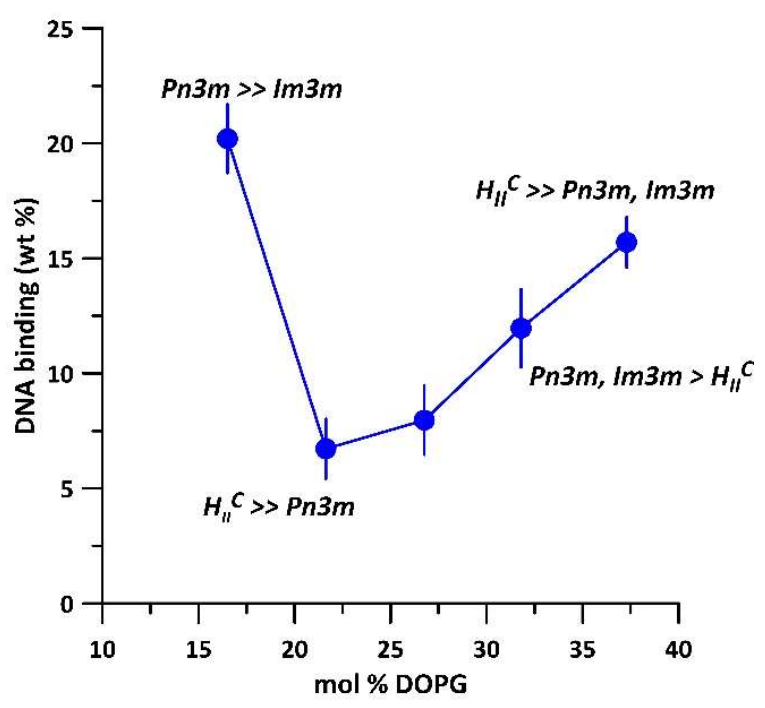

Fig. 8. DNA binding into non-lamellar structures of $D O P G / G M O$ mixtures at different fractions of DOPG (mol \%). The complexes were prepared in $15 \mathrm{mM}^{\circ} \mathrm{CaCl}_{2}$ and $150 \mathrm{mM}$ of $\mathrm{NaCl}$. The amount of bound DNA (in wt\%) is expressed in respect to the total mass of DNA in the sample. The ratios indicate proportionality of individual phases assessed from the relative intensity of the peaks following Fig. 7.

Alongside, UV-vis analysis shows rather low binding of DNA $(\sim 7 \%)$ into $H_{I I}$ phase. The mixtures with DOPG $\geq 26.8 \mathrm{~mol} \%$ show the presence of cubic phases (Pn3m and $\mathrm{Im} 3 \mathrm{~m}$ ) in addition to $H_{I I}$. The fraction of DNA bound in these structures increases up to $\sim 16 \%$. The mixture with $31.8 \mathrm{~mol} \%$ of DOPG shows cubic phases as dominant structures. We found the ratio 65:35 from the sum of intensities of peaks of the cubic phases $(P n 3 m, I m 3 m)$ and $H_{I I}$ phase. To summarize, our experiment reveals higher binding for DNA into cubic structures $(P n 3 m, I m 3 m)$ in comparison to $H_{I I}$ phase.

The precise location of the DNA strands within structures of non-lamellar phases was not determined in this experimental study. Our analysis shows that the radii $\left(r_{w}\right)$ of water channels existing within cubic structures exceed significantly the radius of hydrated DNA $\left(r_{D N A}\right)$, while the radius $r_{H w}$ of water tubules of $H_{I I}$ phase is only slightly larger than $r_{D N A}$. For cubic phases detected in DOPG/GMO $-\mathrm{Ca}^{2+}$ (without DNA) $r_{w}$ can be $\sim 3.5$-times larger than $r_{D N A}$. An alternative analysis of structural dimensions of cubic phases is based on a geometric approach (Gulik et al. 1985; Mariani et al. 1988). In this analysis, the inverse bicountinuous phases are described as forming networks of water filled rods of finite length. In Pn3m the rods form a tetrahedral network (4 rods per vertex); in $\operatorname{Im} 3 m$ the network is cubic (6 rods per vertex). The length of each rod, $l_{r}$, can be calculated as $l_{r}=\Lambda$. $a$, where $\Lambda$ is the length of the rod expressed as a fraction of the unit cell length $(\Lambda=\sqrt{3} / 2$ or 1 for Pn $3 m$ or $\operatorname{Im} 3 m$, respectively) (for illustration, see Fig. 4 in Mariani et al. 1988). Using the geometric approach, the radius of water channels, $r_{w}$, was found to be $\sim 0.1 \mathrm{~nm}$ smaller in comparison to IPMS approach (Briggs et al. 1996). Applying this knowledge to lattice parameters listed in Table 2, one can estimate the length of water channels, $l_{r}$, ranging from $\sim 12$ up to $\sim 22 \mathrm{~nm}$ in cubic phases formed by DOPG/GMO- $\mathrm{Ca}^{2+}$. Classic studies revealed double-stranded DNA to behave as a semiflexible polymer, characterized by a bending persistence length $\sim 45 \pm 5 \mathrm{~nm}(\sim 150 \mathrm{bp})$ (Mandelkern et 
al. 1981). However, recent experimental findings indicate greatly enhanced flexibility and twistability of short fragmented DNA $(\sim 100 \mathrm{bp})$ exceeding significantly the theoretical prediction (Cloutier and Widom 2005). Fig. 2b shows the relative distribution of the length of fragments of DNA used in this experiment. Fragments of $20-100 \mathrm{bp}$, with the average $\sim 55$ bp represent almost $\sim 50 \%$ of the DNA content. This short analysis shows that DNA used in our experiment can be "accommodated" in aqueous channels of nonlamellar structures even if assuming its linear conformation with the length $0.33 \mathrm{~nm} /$ base pair (Mandelkern et al. 1981). We found $\sim 7-20 \%$ of total DNA bound within non-lamellar structures and observed significant structural changes due to the interaction of DNA with DOPG/GMO in presence of $15 \mathrm{mM}$ of $\mathrm{CaCl}_{2}$. Lattice parameters of cubic phases shrink reducing $r_{w}$ suggesting an active role of $\mathrm{Ca}^{2+}$ ions in DNA - DOPG/GMO binding. However, zeta potential measurements revealed that $15 \mathrm{mM}$ of $\mathrm{CaCl}_{2}$ screens only partly the negative surface charge of DOPG/GMO vesicles under condition of high ionic strength. According to our experimental protocol, DNA was incubated in $\mathrm{CaCl}_{2}$ solution prior to mixing with DOPG/GMO vesicles. We hypothesize its binding into aqueous channels concurrently with non-lamellar structure formation. Zeta potential shows changes at the level of experimental uncertainty due to DNA binding (Fig. S10, Supplementary material). The quantity of bound DNA is rather low, which can be attributed to low concentration of $\mathrm{CaCl}_{2}$. The $\mathrm{CaCl}_{2}$ concentration, $15 \mathrm{mM}$, was selected on previously reported transfection experiments using $\mathrm{Ca}^{2+}$ mediated DNA binding in anionic lipoplexes (Patil et al. 2004; Srinivasan and Burgess 2009; Barrán-Berdón et al. 2014)

The positive charge of lipoplexes after DNA complexation is generally considered to be necessary to ensure the association of lipoplexes with cell membranes. However, the positive charge of lipoplexes is not an absolute requirement for effective lipofection (Resina et al. 2009) and negative zeta potential values of lipoplexes were reported to be beneficial for in vivo applications (Lee and Huang 1996; Son et al. 2000; Tavitian et al. 2002). Anionic lipidbased complexes prepared with DOPG, nucleic acid and $\mathrm{Ca}^{2+}$ were reported as non-toxic and efficient transfecting in vitro agents in various cell lines (Patil et al. 2004; Srinivasan and Burgess 2009; Kapoor and Burgess 2012). Anionic formulations are useful also in lipofection of cells that are hard to transfect, such as neurons and macrophages (Kelly et al. 2011; Thakor et al. 2009).

\section{Conclusions}

Our experiments focused on the efficiency of non-lamellar, particularly cubic phases, to encapsulate short fragmented DNA. The solubilization of GMO cubic phase by negatively charged DOPG up to the level of unilamellar vesicles and consecutively, reversal formation of cubic phase using $\mathrm{Ca}^{2+}$ cations was tested as a method for DNA encapsulation. The cubic structure swells with increasing content of DOPG. SAXS shows that the cubic structure $(P n 3 m)$ is dominant and preserved up to $\sim 11 \mathrm{~mol} \%$ of DOPG in DOPG/GMO mixtures hydrated by $150 \mathrm{mM} \mathrm{NaCl}$. The high ionic strength screens partly the electrostatic repulsion between DOPG molecules. However, the cubic structure degrades for higher content of DOPG. SANS scattering profiles of DOPG/GMO with DOPG $\geq 20 \mathrm{~mol} \%$ are typical for unilamellar vesicles. The thickness of the DOPG/GMO lipid bilayer $\left(d_{L}\right)$ decreases slightly with increasing fraction 
of DOPG. The addition of a $\mathrm{Ca}^{2+}$ solution shields the electrostatic repulsions of DOPG molecules and thereby the curvature of DOPG/GMO membrane increases. As a result, cubic structures are restored in DOPG/GMO mixtures with DOPG up to $37 \mathrm{~mol} \%$ upon addition of $15 \mathrm{mM}$ of $\mathrm{CaCl}_{2}$. The combination of structural parameters extracted from both SAXS and SANS gives the radius of water nanochannels of $Q_{I I}$ phases, which were evaluated in respect to DNA accommodation. Zeta potential measurements have shown that $15 \mathrm{mM}$ of $\mathrm{CaCl}_{2}$ do not screen completely the negative surface charge of DOPG/GMO and complexes are anionic. $\mathrm{Ca}^{2+}$ was used as a mediator for DNA - DOPG/GMO binding. We find that a hexagonal phase $H_{I I}$ was formed in addition to cubic phases $P n 3 m$ and $I m 3 m$. The higher amount of DNA bounds in a network of cubic structures as compared to the $H_{I I}$ phase in the formed anionic lipoplexes

In summary, the lipoplexes of DOPG/GMO $-\mathrm{Ca}^{2+}$ with DOPG $<50 \mathrm{~mol} \%$ prepared under conditions of physiologically relevant ionic strength $(150 \mathrm{mM})$ and low $\mathrm{CaCl}_{2}$ concentration are anionic. As shown, lattice parameters of formed non-lamellar structures offer enough room to accommodate short fragmented nucleic acids. $\mathrm{Ca}^{2+}$ ions play a dual role: they stimulate nucleic acid binding and also promote and stabilize the formation of non-lamellar phase. Non-lamellar, particularly cubic phases have been reported as promising gene delivery vectors due to their ability to protect nucleic acids against their degradation in plasma, and easier internalization in the cell supported by the propensity of $Q_{I I}$ for pore formation. To the best of our knowledge anionic lipoplexes of $Q_{I I}$ structure have never been tested for transfection efficiency. The findings of this study may be useful in designing a delivery vector based on low toxicity anionic lipids.

Acknowledgements. The authors thank E. Halasova and the staff of Biomedical Center Martin, Jessenius Faculty of Medicine, Comenius University in Bratislava for electrophoretic DNA analysis. SAXS experiments were performed at BL11-NCD beamline at ALBA Synchrotron with the collaboration of ALBA staff. The authors thank ALBA staff for their helpfulness. D.U. and L.H. thank the staff of LLB CEA Saclay for the hospitality and granted beam time at PACE spectrometer. The research leading to these results was supported by grants VEGA 1/0223/20, APVV-17-0250 and JINR project 04-4-1121-2015/2020. This work benefited from the use of the SasView application, originally developed under NSF award DMR-0520547. Sas View contains code developed with funding from the European Union's Horizon 2020 research and innovation programme under the SINE2020 project, grant agreement No 654000.

\section{References}

Angelov B, Angelova A, Filippov SK, Drechsler M, Štěpánek P, Lesieur S (2014) Multicompartment lipid cubic nanoparticles with high protein upload: Millisecond dynamics of formation. ACS Nano 8 (5): 5216-26. https://doi.org/10.1021/nn5012946

Angelov B, Angelova A, Garamus VM, Lebas G, Lesieur S, Ollivon M, Funari SS, Willumeit $\mathrm{R}$, Couvreur P (2007) Small-angle neutron and X-ray scattering from amphiphilic stimuliresponsive diamond-type bicontinuous cubic phase. J Am Chem Soc 129 (44): 13474-79. https://doi.org/10.1021/ja072725+ 
Angelov B, Angelova A, Ollivon M, Bourgaux C, Campitelli A (2003) Diamond-type lipid cubic phase with large water channels. J Am Chem Soc 125 (24): 7188-89. https://doi.org/10.1021/ja034578v

Angelov B, Garamus VM, Drechsler M, Angelova A (2017) Structural analysis of nanoparticulate carriers for encapsulation of macromolecular drugs. J Mol Liquids 235: 83-89. https://doi.org/10.1016/j.molliq.2016.11.064

Angelov B, Ollivon M, Angelova A (1999) X-ray diffraction study of the effect of the detergent octyl glucoside on the structure of lamellar and nonlamellar lipid/water phases of use for membrane protein reconstitution. Langmuir 15: 8225-8234. https://doi.org/10.1021/la9902338

Angelova A, Angelov B, Mutafchieva R, Garamus VM, Lesieur S, Funari SS, Willumeit R, Couvreur P (2011) Swelling of a sponge lipid phase via incorporation of a nonionic amphiphile: SANS and SAXS studies. Progr Colloid Polym Sci 138: 1-6. DOI: 10.1007/978-3-642-19038-4_1

Angelova A, Ollivon M, Campitelli A, Bourgaux C (2003) Lipid cubic phases as stable nanochannel network structures for protein biochip development: X-ray diffraction study. Langmuir 19: 6928-6935. https://doi.org/10.1021/la0345284

Arseneault M, Lafleur M (2006) Isothermal titration calorimetric study of calcium association to lipid bilayers: influence of the vesicle preparation and composition. Chem Phys Lipids 142: 84-93 doi:10.1016/j.chemphyslip.2006.03.003

Awad TS, Okamoto Y, Md Masum S, Yamazaki M (2005) Formation of cubic phases from large unilamellar vesicles of dioleoylphosphatidylglycerol/monoolein membranes induced by low concentrations of $\mathrm{Ca} 2+$. Langmuir 21 (25): 11556-61. doi.org/10.1021/la051782i

Balazs DA, Goodbey W (2011) Liposomes for use in gene delivery. J Drug Deliv 2011: 1-12 doi:10.1155/2011/326497

Barrán-Berdón AL, Yélamos B, Malfois M, Aicart E, Junquera E (2014) $\mathrm{Ca}^{2+}$-mediated anionic lipid-plasmid DNA lipoplexes. Electrochemical, structural and biochemical study. Langmuir 30: 11704-11713. dx.doi.org/10.1021/la502823z

Barreleiro PCA, Olofsson G, Alexandridis P (2000) Interaction of DNA with cationic vesicles: A calorimetric study. J Phys Chem B 104: 7795-7802. https://doi.org/10.1021/jp000636c

Barriga HMG, Holme MN, Stevens MM (2019) Cubosomes:; The next generation of smart lipid nanoparticles? Angw Chem Int Ed 58 (10): 2958-78. doi.org/10.1002/anie.201804067

Brasnett Ch, Longstaff G, Compton L, Seddon A (2017) Effects of cations on the behaviour of lipid cubic phases. Sci Rep 7: 8229. DOI:10.1038/s41598-017-08438-4

Briggs J, Chung H, Caffrey M (1996) The temperature-composition phase diagram and mesophase structure characterization of the monoolein/water system. J Phys II France 6 (5): 723-51. https://doi.org/10.1051/jp2:1996208

Chen J, Guo Z, Tian H, Chen X (2016) Production and clinical development of nanoparticles for gene delivery. Mol Therapy - Methods and Clinical Development 3: 16023. https://doi.org/10.1038/mtm.2016.23

Chen Y, Ma P, Gui S (2014) Cubic and hexagonal liquid crystals as drug delivery systems. BioMed Res International 2014:815981. https://doi.org/10.1155/2014/815981 
Cherezov V, Clogston J, Misquitta Y, Abdel-Gawad W, Caffrey M (2002) Membrane protein crystalization in meso: lipid type-tailoring of the cubic phase Bioph J 83: 3393-3407. doi: 10.1016/S0006-3495(02)75339-3

Clogston J, Caffrey M (2005) Controlling release from the lipidic cubic phase. Amino acids, peptides, proteins and nucleic acids. J Control Release 107: 97-111. doi:10.1016/j.jconrel.2005.05.015

Cloutier TE, Widom J (2005) DNA twisting flexibility and the formation of sharply looped protein-DNA complexes. Proc Natl Acad Sci USA 102: 3645-3650 doi:10.1073/pnas.0409059102

Dittrich M, Brauer Ch, Funari SS, Dobner B, Brezesinski G, Wölk Ch (2018) Interactions of cationic lipids with DNA: A structural approach. Langmuir 34 (49): 14858-68. doi.org/10.1021/acs.langmuir.8b01635

Ekerdt R, Papahadjopoulos D (1982) Intermembrane contact affects calcium binding to phospholipid vesicles. Proc Natl Acad Sci USA 79: 2273-2277. DOI: 10.1073/pnas.79.7.2273

Engström S, Nordén TP, Nyquist H (1999) Cubic phases for studies of drug partition into lipid bilayers. Eur J Pharm Sci 8 (4): 243-54. https://doi.org/10.1016/S0928-0987(99)00012-3

Ewert KK, Evans HM, Zidovska A, Bouxsein NF, Ahmad A, Safinya CR (2006) A columnar phase of dendritic lipid-based cationic liposome-DNA complexes for gene delivery: Hexagonally ordered cylindrical micelles embedded in a DNA honeycomb lattice. J Am Chem Soc 128:3998-4006. https://doi.org/10.1021/ja055907h

Filion MC, Phillips NC (1998) Major limitations in the use of cationic liposomes for DNA delivery. Int J Pharm 162: 159-170. https://doi.org/10.1016/S0378-5173(97)00423-7

Filippov A, Orädd G, Lindblom G (2009) Effect of $\mathrm{NaCl}$ and $\mathrm{CaCl} 2$ on the leteral diffusion of zwitterionic and anionic lipids in bilayers. Chem Phys Lipids 150: 81-87. doi:10.1016/j.chemphyslip.2009.03.007

Fong C, Zhai J, Drummond CJ, Tran N (2020) Micellar Fd3m cubosomes from monoolein long chain unsaturated fatty acid mixtures: Stability on temperature and $\mathrm{pH}$ response. J Coll Interface Sci 566: 98-106. https://doi.org/10.1016/j.jcis.2020.01.041

Galliková D, Liskayová G, Búcsi A, Hubčík L, Martínez JC, Uhríková D (2018) DOPE-Oleic acid-Ca ${ }^{2+}$ as DNA condensing agent. Eur Pharm J 65 (1):1-9. doi.org/10.2478/afpuc2018-0001

Garidel P, Johann Ch, Mennicke L, Blume A (1997) The mixing behavior of pseudobinary phosphatidylcholine-phosphatidylglycerol mixtures as a function of $\mathrm{pH}$ and chain length. Eur Biophys J 26: 447-459. DOI:10.1007/s002490050099

Gershon H, Ghirlando R, Minsky A, Guttman SB (1993) Mode of formation and structural features of DNA-cationic liposome complexes used for transfection. Biochemistry 32:7143-7151 https://doi.org/10.1021/bi00079a011

Graber ZT, Shi Z, Baumgart T (2017) Cations induce shape remodeling of negatively charged phospholipid membranes. Phys Chem Chem Phys 19: 15285-15295. DOI: $10.1039 / \mathrm{c} 7 \mathrm{cp} 00718 \mathrm{c}$

Guinier A, Fournet G (1955) Small Angle Scattering of X-Rays, J. Wiley and Sons, NY

Gulik A, Luzzati V, De Rosa M, Gambacorta A (1985) Structure and polymorphism of bipolar isopranyl ether lipids from archaebacteria. J Mol Biol 182 (1): 131-49. 
doi.org/10.1016/0022-2836(85)90032-4

Helfrich W (1973) Elastic properties of lipid bilayers: Theory and possible experiments. Z Naturforsch 28c: 693-703 https://doi.org/10.1515/znc-1973-11-1209

Huang TC, Toraya H, Blanton TN, Wu Y (1993) X-ray powder diffraction analysis of silver behenate, a possible low-angle diffraction standard. J Appl Crystallogr 26: 180184. https://doi.org/10.1107/S0021889892009762

Hubčík L, Funari SS, Pullmannová P, Devínsky F, Uhríková D (2015) Stimuli responsive polymorphism of $\mathrm{C} 12 \mathrm{NO} / \mathrm{DOPE} / \mathrm{DNA}$ complexes: Effect of $\mathrm{pH}$, temperature and composition. Biochim Biophys Acta - Biomembranes 1848 (5):1127-1138. doi.org/10.1016/j.bbamem.2015.01.020

Huster D, Arnold K, Gawrisch K (2000) Strength of Ca2+ binding to retinal membranes: consequences for lipid organization. Biophys J 78: 3011-3018. doi: $\underline{10.1016 / \text { S0006- }}$ $\underline{3495(00) 76839-1}$

Hyde ST, Andersson S, Ericsson B, Larsson K (1984) A cubic structure consisting of a lipid bilayer forming an infinite periodic minimum surface of the gyroid type in the glycerolmonooleat-water $\quad$ System. $\quad Z \quad$ Kristallogr $\quad$ NCS $168 \quad$ (1-4): 213-19. doi.org/10.1524/zkri.1984.168.1-4.213

Kapoor M, Burgess DJ (2012) Physicochemical characterization of anionic lipid-based ternary siRNA complexes Biochim Biophys Acta 1818: 1603-1612 doi:10.1016/j.bbamem.2012.03.013

Kelly C, Jefferies C, Cryan S-A (2011) Targeted liposomal drug delivery to monocytes and macrophages. J Drug Delivery 2011, ID 727242. doi:10.1155/2011/727241

Kerékgyártó M, Kerekes T, Tsai E, Amirkhanian VD, Guttman A (2012) Light-emitting diode induced fluorescence (LED-IF) detection design for a pen-shaped cartidge based single capillary electrophoresis system. Electrophoresis 33: 2752-2758. DOI 10.1002/elps.201200139

Kim H, Leal C (2015) Cuboplexes: Topologically active siRNA delivery. ACS Nano 9 (10): 10214-26. https://doi.org/10.1021/acsnano.5b03902

Koltover I, Salditt T, Safinya CR (1999) Phase diagram, stability, and overcharging of lamellar cationic lipid- DNA self-assembled complexes. Biophys J 77:915-924. doi.org/10.1016/S0006-3495(99)76942-0

Koltover I, Salditt T, Rädler JO, Safinya CR (1998) An inverted hexagonal phase of cationic liposome-DNA complexes related to DNA release and delivery. Science 281:78-81 https://doi.org/10.1126/science.281.5373.78

Koynova R, Wang L, MacDonald RC (2006) An intracellular lamellar-nonlamellar phase transition rationalizes the superior performance of some cationic lipid transfection agents. Proc Nat Acad Sci USA 103 (39): 14373-78. https://doi.org/10.1073/pnas.0603085103

Kučerka N, Dushanov E, Kholmurodov KT, Katsaras J, Uhríková D (2017) Calcium and zinc differentially affect the structure of lipid membranes. Langmuir 33: 3134-3141 DOI: 10.1021/acs.langmuir.6b03228

Kučerka N, Ermakova E, Dushanov E, Kholmurodov KT, Kurakin S, Želinská K, Uhríková D (2021) Cation-zwitterionic lipid interactions are affected by the lateral area per lipid. Langmuir 37(1):278-288 https://doi.org/10.1021/acs.langmuir.0c02876

Kučerka N, Nagle JF, Sachs JN, Feller SE, Pencer J, Jackson A, Katsaras J (2008) Lipid bilayer 
structure determined by the simultaneous analysis of neutron and X-ray scattering data. Biophys J 95:2356-2367. https://doi.org/10.1529/biophysj.108.132662

Lasic DD (1997) Liposomes in gene delivery, CRC Press Inc., Boca Raton, FL

Lasic DD, Strey H, Stuart MCA, Podgornik R, Frederik PM (1997) The structure of DNA liposome complexes. J Am Chem Soc 119: 832-833. https://doi.org/10.1021/ja962713g Lavigne C, Slater K, Gajanayaka N, Duguay Ch, Peyrotte EA, Fortier G, Simard M, Kell AJ, Barnes ML, Thierry AR (2013) Influence of lipoplex surface charge on siRNA delivery: application to the in vitro downregulation of $\mathrm{CXCR}_{4} \mathrm{HIV}-1$ co-receptor. Expert Opin Biol Ther 13:973-985. doi: 10.1517/14712598.2013.743526.

Leal C, Bouxsein NF, Ewert KK, Safinya CR (2010) Highly efficient gene silencing activity of siRNA embedded in a nanostructured gyroid cubic lipid matrix. J Am Chem Soc 132: 16841-47. https://doi.org/10.1016/j.bpj.2008.12.2313

Leal C, Ewert KK, Bouxsein NF, Shirazi RS, Li Y, Safinya CR (2013) Stacking of short DNA induces the gyroid cubic-to-inverted hexagonal phase transition in lipid-DNA complexes. Soft Matter 9 (3): 795-804. https://doi.org/10.1039/c2sm27018h

Lee RJ, Huang L (1996) Folate-targeted, anionic liposome-entrapped polylysinecondensed DNA for tumor cell-specific gene transfer. J Biol Chem 271:8481-8487. doi: $10.1074 / j b c .271 .14 .8481$

Lei N, Safinya CR, Roux D, Liang KS (1997) Synchrotron X-ray-scattering studies on the sodium dodecyl sulfate-water-pentanol-dodecane L3 sponge phase. Physic Rev E 56 (1 SUPPL. B): 608-13. https://doi.org/10.1103/physreve.56.608

Lengyel A, Uhríková D, Klacsová M, Balgavý P (2011) DNA condensation and its thermal stability influenced by phospholipid bilayer and divalent cations. Coll Surf B: Biointerfaces 86 (1): 212-17. https://doi.org/10.1016/j.colsurfb.2011.04.001

Liskayová G, Hubčík L, Búcsi A, Fazekaš T, Martínez JC, Devínsky F, Pisárčik M, Hanulová M, Ritz S, Uhríková D (2019) pH-sensitive N, N-dimethylalkane-1-amine N-oxides in DNA delivery: from structure to transfection efficiency. Langmuir 35 (41):13382-13395. https://doi.org/10.1021/acs.langmuir.9b02353

Luzzati V (1997) Biological significance of lipid polymorphism: the cubic phases. Curr Opinion Struct Biol 7: 661-668. https://doi.org/10.1016/S0959-440X(97)80075-9

Luzzati V, Vargas R, Mariani P, Gulik A, Delacroix H (1993) Cubic phases of lipid-containing systems: elements of a theory and biological connotations. J Mol Biol 229: 540-551. https://doi.org/10.1006/jmbi.1993.1053

MacDonald RC, MacDonald RI, Menco BPhM, Takeshita K, Subbarao NK, rong Hu L (1991) Small-volume extrusion apparatus for preparation of large, unilamellar vesicles. Biochim Biophys Acta - Biomembranes 1061:297-303. doi.org/10.1016/0005-2736(91)90295-J

Macdonald PM, Seelig J (1987) Calcium binding to mixed phosphatidylglycerolphosphatidylcholine bilayers as studied by deuterium nuclear magnetic resonance. Biochemistry 26: 1231-1240 DOI: 10.1021/bi00379a005

Mandelkern M, Elias JG, Eden D, Crothers DM (1981) The dimensions of DNA in solution. J Mol Biol 152 (1): 153-61. https://doi.org/10.1016/0022-2836(81)90099-1

Mariani P, Luzzati V, Delacroix H (1988) Cubic phases of lipid-containing systems. Structure analysis and biological implications. J Mol Biol 204: 165-189. DOI: 10.1016/00222836(88)90607-9 
Mariani P, Rustichelli F, Saturni L, Cordone L (1999) Stabilization of the monoolein Pn3m cubic structure on trehalose glasses. Eur Biophys J 28 (4): 294-301. doi.org/10.1007/s002490050211

Marsh D (1996) Intrinsic curvature in normal and inverted lipid structures and in membranes. Biophys J 70 (5): 2248-55. https://doi.org/10.1016/S0006-3495(96)79790-4

Melcrová A, Pokorna S, Pullanchery S, Kohagen M, Jurkiewicz P, Hof M, Jungwirth P, Cremer PS, Cwiklik L (2016) The complex nature of calcium cation interactions with phospholipid bilayers. Sci Rep 6: 38035 DOI: 10.1038/srep38035

Pan J, Heberle FA, Tristram-Nagle S, Szymanski M, Koepfinger M, Katsaras J, Kučerka N (2012) Molecular structures of fluid phase phosphatidylglycerol bilayers as determined by small angle neutron and X-ray scattering. Biochim Biophys Acta - Biomembranes 1818 (9): 2135-48. https://doi.org/10.1016/j.bbamem.2012.05.007

Patil SD, Rhodes DG, Burgess DJ (2004) Anionic liposomal delivery system for DNA transfection. AAPS J 6:13-22. doi: 10.1208/aapsj060429

Porte G (1992) Lamellar phases and disordered phases of fluid bilayer membranes. J Phys: Condensed Matter 4 (45): 8649-70. https://doi.org/10.1088/0953-8984/4/45/002

Qiu H, Caffrey M (2000) The phase diagram of the monoolein/water system: metastability and equilibrium aspects. Biomaterials 21: 223-234. doi: 10.1016/s0142-9612(99)00126-X

Pullmannová P, Bastos M, Bai G, Funari SS, Lacko I, Devínsky F, Teixeira J, Uhríková D (2012) The ionic strength effect on the DNA complexation by DOPC - gemini surfactants liposomes. Bioph Chem 160: 35-45. doi:10.1016/j.bpc.2011.09.002

Rädler JO, Koltover I, Salditt T, Safinya CR (1997) Structure of DNA-cationic liposome complexes: DNA intercalation in multilamellar membranes in distinct interhelical packing regimes. Science 275:810-814. https://doi.org/10.1126/science.275.5301.810

Resina S, Prevot P, Thierry AR (2009) Physico-chemical characteristics of lipoplexes influence cell uptake mechanisms and transfection eficacy. Plos One 4: e6058. Doi:10.1371/journal.pone.0006058

Safinya CR, Ewert KK, Majzoub RN, Leal C (2014) Cationic liposome-nucleic acid complexes for gene delivery and gene silencing. New J Chem 38 (11): 5164-72. doi.org/10.1039/c4nj01314j

Sarkar S, Tran N, Soni SK, Conn ChE, Drummond CJ (2020) Size-dependent encapsulation and release of dsDNA from cationic lyotropic liquid crystalline cubic phases. ACS Biomater Sci Eng 6 (8): 4401-13. https://doi.org/10.1021/acsbiomaterials.0c00085.

Scriven LE (1976) Equilibrium bicontinuous structure. Nature 263 (5573): 123-25. https://doi.org/10.1038/263123a0

Seddon JM, Templer RH (1993) Cubic phases of self-assembled amphiphilic aggregates. Philos Trans R Soc A 344 (1672): 377-401. https://doi.org/10.1098/rsta.1993.0096

Seelig J (1990) Interaction of phospholipids with $\mathrm{Ca}^{2+}$ ions. On the role of the phospholipid head groups. Cell Biol Int Rep 14: 353-360. doi: 10.1016/0309-1651(90)91204-h

Shah JC, Sadhale Y, Chilukuri DM (2001) Cubic phase gels as drug delivery systems. Adv Drug Deliv Rev 47:229-250. https://doi.org/10.1016/S0169-409X(01)00108-9

Siegel DP (1999) The modified stalk mechanism of lamellar/inverted phase transitions and its implications for membrane fusion. Biophys J 76 (1 I): 291-313. doi.org/10.1016/S00063495(99)77197-3 
Sinn CG, Antonietti M, Dimova R (2006) Binding of calcium to phosphatidylcholine phosphatidylserine membranes. Coll Surf A 282-283: 410-419. doi:10.1016/j.colsurfa.2005.10.014

Son KK, Tkach D, Hall KJ (2000) Efficient in vivo gene delivery by the negatively charged complexes of cationic liposomes and plasmid DNA. Biochim Biophys Acta 1468:6-10. doi: 10.1016/s0005-2736(00)00311-4

Srinivasan Ch, Burgess DJ (2009) Optimization and characterization of anionic lipoplexes for gene delivery J Contr Release 136: 62-70. doi:10.1016/j.jconrel.2009.01.022

Tassler S, Dobner B, Lampp L, Ziółkowski R, Malinowska E, Wölk Ch, Brezesinski G (2019) DNA delivery systems based on peptide-mimicking cationic lipids - the effect of the colipid on the structure and DNA binding capacity. Langmuir 35 (13): 4613-25. https://doi.org/10.1021/acs.langmuir.8b04139

Tavitian B, Marzabal S, Boutet V, Kühnast B, Terrazzino S, Moynier M, Thierry AR (2002) Characterization of a synthetic anionic vector for oligonucleotide delivery using in vivo whole body dynamic imaging. Pharm Res 19:367-376. https://doi.org/10.1023/A:1015133205457

Templer RH (1998) Thermodynamic and theoretical aspects of cubic mesophases in nature and biological amphiphiles. Curr Opin Colloid Interface Sci 3 (3): 255-63. doi.org/10.1016/S1359-0294(98)80069-1

Tenchov BG, Wang L, Koynova R, MacDonald RC (2008) Modulation of a membrane lipid lamellar-lonlamellar phase transition by cationic lipids: A measure for transfection efficiency. Biochim Biophys Acta - Biomembranes 1778 (10): 2405-12. doi.org/10.1016/j.bbamem.2008.07.022

Thakor DK, Teng YD, Tabata Y (2009) Neuronal gene delivery by negatively charged pullulan-spermine/DNA anioplexes. Biomaterials 30: 1815-1826. doi:10.1016/j.biomaterials.2008.12.032

Turner DC, Wang Z-G, Gruner SM, Mannock DA, McElhaney RN (1992) Structural study of the inverted cubic phases of di-dodecyl alkyl-beta-D-glucopyranosyl-rac-glycerol. J. Phys. II France 2: 2039-63. doi:10.1051/jp2:1992250

Tyler AII, Barriga HMG, Parsons ES, McCarthy NLC, Ces O, Law RV, Seddon JM, Brooks NJ (2015) Electrostatic swelling of bicontinuous cubic lipid phases. Soft Matter 11:32793286. doi: $10.1039 / \mathrm{c} 5 \mathrm{sm} 00311 \mathrm{c}$

Uhríková D, Kučerka N, Teixeira J, Gordeliy V, Balgavý P (2008) Structural changes in dipalmitoylphosphatidylcholine bilayer promoted by $\mathrm{Ca} 2+$ ions: A small-angle neutron $\begin{array}{lllllll}\text { scattering study. Chem } & \text { Phys } & \text { (2): } & \text { Lipids }\end{array}$ doi.org/10.1016/j.chemphyslip.2008.07.010

Uhríková D, Pullmannová P (2014) Structural diversity of DNA-phospholipid aggregates. In: Pabst G, Kučerka N, Nieh M-P, Katsaras J (eds). Liposomes, Lipid Bilayers and Model Membranes. CRC Press, Boca Raton, FL, pp 247-270 https://doi.org/10.1201/b16617-15. Uhríková D, Teixeira J, Lengyel A, Almásy L, Balgavý P (2007) Formation of unilamellar dipalmitoylphosphatidylcholine vesicles promoted by $\mathrm{Ca} 2+$ ions: A small-angle nutron scattering study. Spectroscopy - Int. J. 21 (1): 43-52 https://doi.org/10.1155/2007/576282

Yaghmur A, Laggner P, Sartori B, Rappolt M (2008) Calcium triggered $\mathrm{L} \alpha-\mathrm{H}_{2}$ phase transition monitored by combined rapid mixing and time-resolved synchrotron SAXS. Plos One 3: 
e2072. doi:10.1371/journal.pone.0002072

Yaghmur A, Sartori B, Rappolt M (2013) The role of calcium in membrane condensation and spontaneous curvature variations in model lipidic systems. Phys. Chem. Chem. Phys. 13: 3115-3125. doi: $10.1039 / \mathrm{c} 0 \mathrm{cp} 01036 \mathrm{~g}$

Yaghmur A, Rappolt M (2013) The micellar cubic Fd3m phase. Recent advances in the structural characterization and potential applications. In: Iglič A, Kulkarni ChV (eds), Advances in Planar Lipid Bilayers and Liposomes 18:111-145. https://doi.org/10.1016/B978-0-12-411515-6.00005-9

Zhai J, Fong C, Tran N, Drummond CJ (2019) Non-lamellar lyotropic liquid crystalline lipid nanoparticles for the next generation of nanomedicine. ACS Nano 13 (6): 6178-6206. https://doi.org/10.1021/acsnano.8b07961

Graphical Abstract:

\section{DNA + DOPG/GMO + $\mathrm{Ca}^{2+}$}

DNA binding: $\mathrm{Pn} 3 \mathrm{~m}, \mathrm{Im} 3 \mathrm{~m}>\mathrm{H}_{\|}$

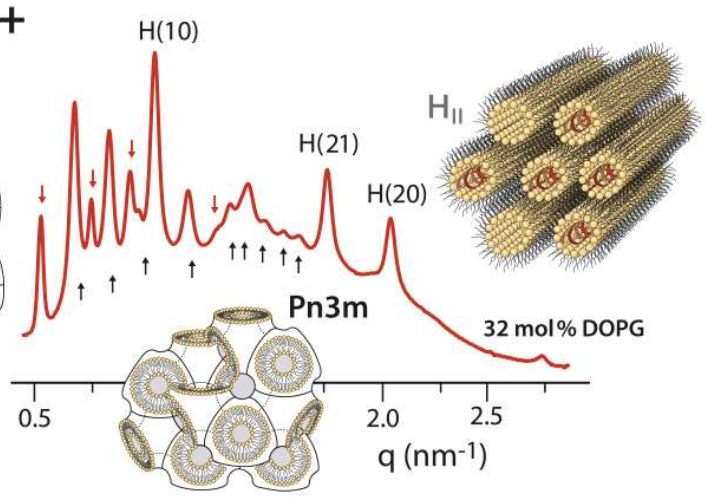

